\title{
Physico-chemical and biological factors influencing dinoflagellate cyst production in the Cariaco Basin
}

\author{
Manuel Bringué $^{1,2, a}$, Robert C. Thunell ${ }^{1}$, Vera Pospelova ${ }^{2}$, James L. Pinckney ${ }^{1,3}$, Oscar E. Romero ${ }^{4}$, and \\ Eric J. Tappa ${ }^{1}$ \\ ${ }^{1}$ School of the Earth, Ocean and Environment, University of South Carolina, 701 Sumter Street, EWS 617, \\ Columbia, SC 29208, USA \\ ${ }^{2}$ School of Earth and Ocean Sciences, University of Victoria, P.O. Box 1700, STN CSC, Victoria, BC, V8W 2Y2, Canada \\ ${ }^{3}$ Belle W. Baruch Institute for Marine and Coastal Sciences, University of South Carolina, 700 Sumter Street, \\ EWS 604, Columbia, SC 29208, USA \\ ${ }^{4}$ MARUM, Center for Marine Environmental Sciences, University Bremen, Leobenerstraße, 28359 Bremen, Germany \\ anow at: Geological Survey of Canada, 3303 33rd Street NW, Calgary, AB, T2L 2A7, Canada
}

Correspondence: Manuel Bringué (manuel.bringue@canada.ca)

Received: 20 November 2017 - Discussion started: 22 November 2017

Revised: 19 March 2018 - Accepted: 25 March 2018 - Published: 19 April 2018

\begin{abstract}
We present a 2.5-year-long sediment trap record of dinoflagellate cyst production in the Cariaco Basin, off Venezuela (southern Caribbean Sea). The site lies under the influence of wind-driven, seasonal upwelling which promotes high levels of primary productivity during boreal winter and spring. Changes in dinoflagellate cyst production is documented between November 1996 and May 1999 at $\sim$ 14-day intervals and interpreted in the context of in situ observations of physico-chemical and biological parameters measured at the mooring site.

Dinoflagellate cyst assemblages are diverse (57 taxa) and dominated by cyst taxa of heterotrophic affinity, primarily Brigantedinium spp. (51\% of the total trap assemblage). Average cyst fluxes to the trap are high $\left(17.1 \times 10^{3}\right.$ cysts $^{-2}$ day $\left.^{-1}\right)$ and show great seasonal and interannual variability. On seasonal timescales, dinoflagellate cyst production responds closely to variations in upwelling strength, with increases in cyst fluxes of several protoperidinioid taxa observed during active upwelling intervals, predominantly Brigantedinium spp. Cyst taxa produced by autotrophic dinoflagellates, in particular Bitectatodinium spongium, also respond positively to upwelling. Several "spiny brown" cysts contribute substantially to the assemblages, including Echinidinium delicatum (9.7\%) and Echinidinium granulatum $(7.3 \%)$, and show a closer affinity to weaker upwelling conditions. The strong El Niño event of 1997/98 appears to have negatively impacted cyst pro-
\end{abstract}

duction in the basin with a 1-year lag, and may have contributed to the unusually high fluxes of cysts type "Cp" (possibly the cysts of the toxic dinoflagellate Cochlodinium polykrikoides sensu Li et al., 2015), with cyst type Cp fluxes up to $11.8 \times 10^{3}$ cysts $\mathrm{m}^{-2}$ day $^{-1}$ observed during the weak upwelling event of February-May 1999.

Possible trophic interactions between dinoflagellates and other major planktonic groups are also investigated by comparing the timing and magnitude of cyst production with proxies for phytoplanktonic communities (from photopigment data) and micro- to macrozooplankton abundance indicators (from palynological data) at the site. This work provides new, detailed insights into the ecology of cystproducing dinoflagellates and will allow for more detailed interpretations of fossil assemblages extracted from sedimentary records in the basin and elsewhere.

Copyright statement. The works published in this journal are distributed under the Creative Commons Attribution 4.0 License. This license does not affect the Crown copyright work, which is re-usable under the Open Government Licence (OGL). The Creative Commons Attribution 4.0 License and the OGL are interoperable and do not conflict with, reduce or limit each other.

(C) Crown copyright 2018 


\section{Introduction}

The Cariaco Basin, located off the coast of Venezuela, harbours one of the most productive ecosystems in the Caribbean Sea (e.g., Müller-Karger and Castro, 1994; Antoine et al., 1996; Rueda-Roa and Müller-Karger, 2013). Seasonal trade-wind-driven upwelling promotes high levels of primary productivity in the southern Caribbean upwelling system, typically during boreal winter and spring, with secondary upwelling events often observed in the basin in July and August (e.g., Müller-Karger and Castro, 1994; Astor et al., 2003; Rueda-Roa, 2012). Microbial respiration of sinking organic matter, together with restricted bottom water ventilation in the basin, have led to the formation of permanent anoxic conditions below $\sim 275 \mathrm{~m}$ (Richards and Vaccaro, 1956; Deuser, 1973; Astor et al., 2003). The succession of high fluxes of biogenic components (carbonate, opal, and organic matter) during active upwelling intervals and dominantly lithogenous material during the rainy season (Thunell et al., 2000; Goñi et al., 2003) is well reflected in the sediments (Peterson et al., 1991; Hughen et al., 1996). In turn, the sedimentary record of the basin is widely used as a repository of past climate and environmental change in the region (e.g., Hughen et al., 1996, 2000; Black et al., 1999, 2007; Peterson et al., 1991, 2000).

Station CARIACO has been under high-frequency hydrographic and biogeochemical monitoring since 1995, with monthly water column sampling and continuous deployment of sediment traps conducted as part of the Cariaco Ocean Time-Series Program (Thunell et al., 2000; Müller-Karger et al., 2001). This United States-Venezuelan research effort constitutes a unique opportunity to investigate biogeochemical and ecological processes that take place in the water column, their temporal evolution, and how these processes are encoded in the settling flux of particles (e.g., Ho et al., 2002; Astor et al., 2003; Goñi et al., 2003; Taylor et al., 2012; Marshall et al., 2013; Montes et al., 2013; Calvert et al., 2015). Here, we present the first study to focus on dinoflagellate cyst production in the Caribbean Sea, using sediment trap samples collected over a 2.5-year period at station CARIACO.

Dinoflagellates are aquatic protists that form an important component of marine plankton in terms of diversity and biomass, both as primary producers and as heterotrophic grazers on a wide range of phyto- and zooplanktonic organisms (e.g., Taylor, 1987; Jacobson and Anderson, 1996; Jeong, 1999; Calbet, 2008). In addition to their key role in coastal marine food webs, dinoflagellates are a valuable tool to investigate the history of changes in sea-surface conditions and planktonic communities (e.g., Dale, 1996; de Vernal et al., 2001; Harland et al., 2013; Bringué et al., 2014; Pospelova et al., 2015; Ellegaard et al., 2017), since many dinoflagellates produce resting cysts as part of their life cycle that are well preserved in fine-grained sediments over geologic times. Establishing the detailed environmental preferences and controls over cyst-producing dinoflagellates has been the focus of many studies over the last few decades, and has traditionally been tackled by studying the distribution of cysts in "surface" sediments in relation to (multi-)annually averaged sea-surface conditions (e.g., Rochon et al., 1999; Zonneveld et al., 2013, and references therein). Alternatively, sediment trap records can resolve the seasonality in cyst production and thus considerably improve the reliability of environmental signals associated with each dinoflagellate species (e.g., Dale, 1992; Dale and Dale, 1992; Morquecho and Lechuga-Deveze, 2004; Susek et al., 2005; Fujii and Matsuoka, 2006; Pitcher and Joyce, 2009; Howe et al., 2010; Pospelova et al., 2010, 2018; Zonneveld et al., 2010; Price and Pospelova, 2011; Bringué et al., 2013; Prebble et al., 2013; Heikkilä et al., 2016).

Since the early work of Wall (1967) on five sub-samples of a core from the Cariaco "Trench", the dinoflagellate cyst sedimentary record of the basin has subsequently been studied by González et al. (2008; 73 to 30 ka interval) and Mertens et al. (2009a; last $30 \mathrm{ka}$ ) at multi-centennial to millennial resolutions. This study focusses on seasonal cyst production as a calibration effort for the interpretation of fossil assemblages from the basin's pristine sedimentary record and elsewhere.

Our objectives are (1) to document the seasonal changes in dinoflagellate cyst production in the basin, (2) to relate cyst production to physico-chemical parameters (e.g., temperature, salinity, nutrients), and (3) to investigate the relationships between dinoflagellate species and other major planktonic groups (e.g., diatoms, haptophytes, copepods) based on in situ observations.

\section{Environmental setting}

The Cariaco Basin is a $1400 \mathrm{~m}$ deep depression on the continental shelf off Venezuela in the southern Caribbean Sea (Fig. 1). The western and eastern sub-basins, separated by an $\sim 900 \mathrm{~m}$ deep saddle, are partially isolated from the Caribbean and Atlantic waters by a shallow $(\sim 100 \mathrm{~m})$ ridge on its northern flank that is only cut by two small channels: Canal Centinela (146 m) and Canal de la Tortuga (135 m).

Surface waters originate in the North Equatorial and Guyana currents and enter the Caribbean Sea from the southeast (Gordon, 1967; Richards, 1975). Waters from the Amazon and Orinoco rivers that may be transported into the Caribbean have little influence on the hydrography of the basin (Müller-Karger et al., 1989). Below sill depth, the combination of restricted water circulation, a steep density gradient over the upper $150 \mathrm{~m}$, and a high flux of organic matter settling in the basin results in slow renewal of deep waters and permanent anoxic conditions below $\sim 275 \mathrm{~m}$ (Richards and Vaccaro, 1956; Deuser, 1973; Thunell et al., 2000; Astor et al., 2003). Observations and models of water masses horizontal velocities in the basin indicate that horizontal transport is weak in the upper water column ( $U$ and $V$ components $<0.2 \mathrm{~m} \mathrm{~s}^{-1}$ ) and negligible below sill depth (Alvera- 


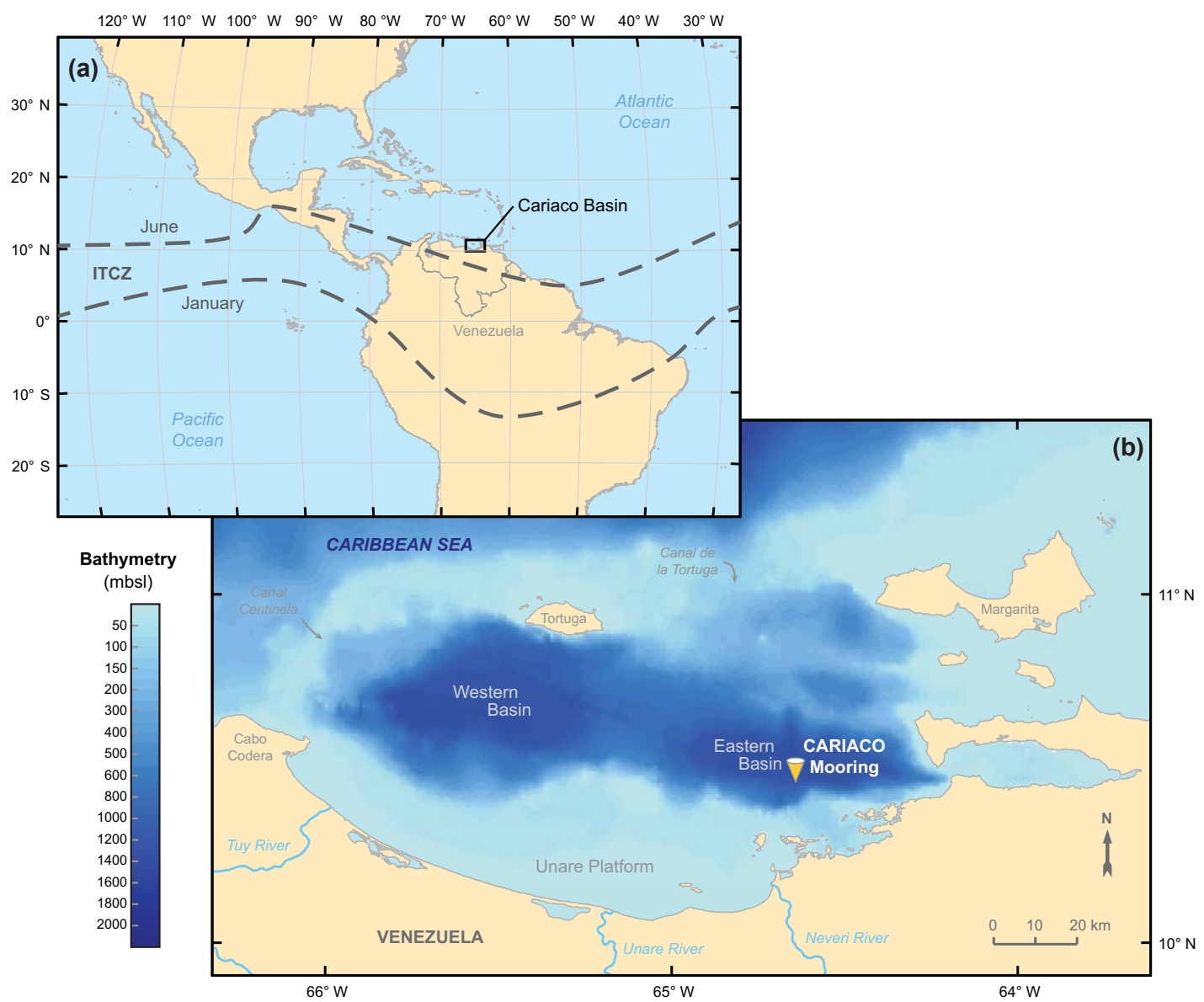

Figure 1. (a) Location of the Cariaco Basin in the southern Caribbean Sea, with boreal winter and summer positions of the Intertropical Convergence Zone (ITCZ) indicated as dashed lines. (b) Map showing the main bathymetric features, local rivers emptying in the basin, and the location of CARIACO station in the eastern sub-basin.

Azcárate et al., 2009), indicating a minimal potential for horizontal cyst transport at station CARIACO.

Primary production in the Cariaco Basin is high $\left(>300 \mathrm{~g} \mathrm{C} \mathrm{m}^{-2} \mathrm{yr}^{-1}\right.$ ) and shows great seasonal and interannual variability (e.g., Müller-Karger et al., 2001, 2004). Seasonal upwelling of Subtropical Underwater (SUW), a water mass characterized by a salinity of 36.9 and a nitrate concentration of 5-10 $\mu \mathrm{M}$ (Morrison and Smith, 1990), is controlled by the position of the Intertropical Convergence Zone (ITCZ). When the ITCZ lies south of the equator (typically from December to April), strong E-NE trade winds $\left(>6 \mathrm{~m} \mathrm{~s}^{-1}\right)$ induce wind-driven upwelling along the coastline, bringing nutrients to the surface and fostering high levels of primary productivity (e.g., Richards, 1975; MüllerKarger et al., 2001). During the summer/fall rainy season, the ITCZ migrates to its northern position, winds weaken, and upwelling ceases, although shorter secondary upwelling events are often observed in July and August (e.g., Astor et al., 2003; Goñi et al., 2003). Interannual variability in primary productivity at the CARIACO station (east- ern basin; Fig. 1) is also pronounced, with annually integrated measurements between 1996 and 2001 ranging from $\sim 370$ to $650 \mathrm{~g} \mathrm{C} \mathrm{m}^{-2} \mathrm{yr}^{-1}$ (Müller-Karger et al., 2004). Surface salinity at the CARIACO station varies from $>36.8$ in January-July to $<36.6$ during the rainy season (Astor et al., 2003). The depth of the euphotic zone (defined as the depth of $1 \%$ photosynthetic active radiation level), measured between 1995 and 2005, was usually shallower under active upwelling conditions $(36.7 \pm 12.3 \mathrm{~m})$ than during the rainy season (47.9 $\pm 13.5 \mathrm{~m}$; Lorenzoni et al., 2011).

Phases of the North Atlantic Oscillation (NAO), defined as the difference in sea level pressure anomalies between the Azores High and the Icelandic Low, are known to modulate precipitation in the Caribbean (Giannini et al., 2001) but appear to have limited impact on sea-surface temperature (SST) patterns and hydrography of the basin (Taylor et al., 2012; Astor et al., 2013). The El Niño-Southern Oscillation (ENSO) phenomenon, which affects a major portion of the tropical Pacific, the Americas, and the Caribbean through atmospheric teleconnections, has been shown to influence pre- 
cipitation, SST, and productivity patterns at the CARIACO station with a 1-year lag (Enfield and Mayer, 1997; Giannini et al., 2001; Taylor et al., 2012; Astor et al., 2013), and may cause shifts in phytoplankton communities in the basin (Goñi et al., 2003; Romero et al., 2009).

The high levels of primary productivity result in the export of large fluxes of particulate organic matter to the depths (Thunell et al., 2000, 2007), while local rivers (Tuy, Unare, and Neveri) deliver the bulk of terrigenous sediments to the basin (e.g., Elmore et al., 2009; Bout-Roumazeilles et al., 2013). The succession of intervals of high surface productivity during active upwelling (and associated flux of biogenic material), and periods of low productivity and rainy conditions when sedimentation is dominated by lithogenous particles, is reflected in the laminated sediments that accumulate under anoxic conditions in the basin (e.g., Peterson et al., 1991; Hughen et al., 1996; Thunell et al., 2000; Goñi et al., 2003).

\section{Material and methods}

\subsection{Sample collection and analyses}

All samples used in this study were collected as part of the Cariaco Ocean Time-Series Program at a station located in the eastern basin $\left(10^{\circ} 30^{\prime} \mathrm{N}, 64^{\circ} 40^{\prime} \mathrm{W}\right.$; Fig. 1). The program has been collecting oceanographic observations since 1995, with monthly water column sampling and nearly continuous deployment of sediment traps at the CARIACO station (Thunell et al., 2000; Müller-Karger et al., 2001). Conductivity-Temperature-Depth (CTD) casts (providing SST; sea surface salinity, SSS; and density, $\sigma_{T}$, profiles) and water column sampling at discrete depths using a rosette equipped with 12 Teflon-coated Niskin bottles (for measurements of various parameters including dissolved oxygen, $\mathrm{pH}$, alkalinity, chlorophyll $a$ concentrations, rates of primary productivity, suspended particulate organic carbon and nitrogen, phaeopigments, and nutrients) were performed on a monthly basis. An overview of the program and methods is provided in Müller-Karger et al. (2001), and sampling, analytical procedures, and data can be found at www.imars.usf.edu/cariaco.

Four Mark-VII automated sediment traps (Honjo and Doherty, 1988) were deployed on a single mooring at depths of $275 \mathrm{~m}$ (Trap A), $455 \mathrm{~m}$ (B), $930 \mathrm{~m}$ (C), and $1255 \mathrm{~m}$ (D) at the CARIACO station, as described in Thunell et al. (2000). The conical traps have an aperture of $0.5 \mathrm{~m}^{2}$ and are equipped with a baffle to reduce turbulence over the collection area. Thirteen cups filled with a buffered formalin solution (as a preservative for the organic matter) were mounted on a carousel with a rotating frequency of two weeks, except for a few cups that collected sediments for 7-12 days. The mooring was recovered and redeployed every 6 months. The present study focusses on samples from Trap A $(275 \mathrm{~m})$ col- lected during deployments 3 to 7, i.e., between 8 November 1996 and 3 May 1999.

Upon recovery, sediment trap samples were stored in sealed containers and kept refrigerated in the dark. Wholetrap samples were split using a precision rotary splitter and swimmers that are not part of the particle flux were removed before analyses. Quarter splits were thoroughly rinsed, oven$\left(50^{\circ} \mathrm{C}\right)$ or freeze-dried, weighed, and used for geochemical analyses. Contents of particulate organic carbon (hereafter $\mathrm{C}_{\text {org }}$ ) and particulate organic nitrogen $(\mathrm{N})$ were measured using a Perkin-Elmer 2400 elemental analyzer; biogenic silica (bioSi) was analysed following the method of Mortlock and Froelich (1989) and carbonate $\left(\mathrm{CaCO}_{3}\right)$ content was determined using the method described in Osterman et al. (1990) (Thunell et al., 2000, 2007). Sixteenth (1/16) splits of wholetrap samples were used for palynological analyses, as described below (Sect. 3.2).

This study uses some previously published data, for means of interpretation of dinoflagellate cyst data in the context of other important planktonic groups in the basin. In particular, diatom and silicoflagellate census data, determined from different splits of the same sediment trap samples, were obtained from Romero et al. (2009), and high performance liquid chromatography (HPLC) measurements of photopigments, analysed from monthly water column sampling at the CARIACO station, were obtained from Pinckney et al. (2015).

\subsection{Palynological preparation}

The 62 sediment trap samples, representing $1 / 16$ splits of all Trap A $(275 \mathrm{~m})$ cups from deployments 3 through 7, were processed in the Paleoenvironmental / Marine Palynology Laboratory at the University of Victoria (BC, Canada). Dinoflagellate cysts and other palynomorphs (including pollen grains and spores, micro-foraminiferal organic linings, copepod eggs, and dinoflagellate thecae) were extracted using the palynological processing technique described by Pospelova et al. (2010) to ensure optimal recovery of all palynomorphs. Sediment trap samples were rinsed 3 times to remove salt residue, oven dried at $40^{\circ} \mathrm{C}$, and weighed with an analytical balance. One calibrated tablet of Lycopodium clavatum (batch no. 3862, produced and distributed by the Department of Quaternary Geology, University of Lund, Sweden) was added to each sample in order to estimate palynomorph concentrations (Stockmarr, 1971; Mertens et al., 2009b, 2012). Samples were treated with room temperature $10 \% \mathrm{HCl}$ to remove carbonates. Particles finer than $15 \mu \mathrm{m}$ and coarser than $120 \mu \mathrm{m}$ were eliminated by wet sieving through Nitex nylon meshes. Samples were then exposed to room temperature $48 \% \mathrm{HF}$ for 2-3 days to remove silicates, followed by a second $10 \% \mathrm{HCl}$ treatment to eliminate precipitated fluorosilicates. After each step, samples were rinsed with reversed osmosis water and centrifuged at $3600 \mathrm{rpm}$ for 6 minutes. Samples were gently sonicated for up to 1 minute (Price et 
al., 2016) and collected on a $15 \mu \mathrm{m}$ mesh. One or two drops of residue were mounted in glycerine jelly between a slide and cover slip.

Dinoflagellate cysts and other palynomorphs were identified and counted using Nikon Eclipse transmitting light microscopes (models E200 and 80i) at $500 \times, 600 \times$ and $1000 \times$ magnifications. A minimum of 300 cysts per sample were counted, except in six cases where the splits did not contain enough cysts or when that number could not be reached after counting two full slides. In two instances, pairs of adjacent samples representing only 7 days of sediment collection each (and yielding very little material) were combined together, and each couplet was treated as one sample of 14 days, with flux data for individual taxa calculated as an average of the fluxes in the two 7-day samples (Table S1 in the Supplement). Overall, between 126 and 460 cysts were counted per sample, with an average of 316. Palynomorph fluxes are expressed as specimens per square metre per day.

The error in cyst fluxes was estimated as in Bringué et al. (2014) by adding the systematic error in flux estimates associated with the L. clavatum tablets $(9.82 \%$; Maher, 1981) and the statistical error in counts $(10.1 \%$, considering both L. clavatum and dinoflagellate cyst counts) in quadrature, resulting in a total error in cyst flux estimates of $14.1 \%$. All samples and slides are stored at the Paleoenvironmental / Marine Palynology Laboratory, School of Earth and Ocean Sciences, University of Victoria, Canada.

\subsection{Dinoflagellate cyst nomenclature}

The dinoflagellate cyst nomenclature follows the palaeontological taxonomy system provided in Lentin and Williams (1993) (recently updated in Williams et al., 2017) and conforms to taxonomic descriptions provided by Margalef (1961), Wall and Dale (1966, 1968, 1969), Reid (1977), Matsuoka et al. (1990, 2006, 2009), Zonneveld (1997), Ellegaard and Moestrup (1999), Head (1996, 2002), Rochon et al. (1999), Zonneveld and Jurkschat (1999), Verleye et al. (2011), Mertens et al. (2013), and Liu et al. (2015), with most cyst description summaries and corresponding motile dinoflagellate names provided in Zonneveld and Pospelova (2015).

The cysts of cf. Biecheleria sp., Echinidinium cf. delicatum and cyst type M1 were identified as in Bringué et al. (2014, 2016). The cysts of cf. Ensiculifera carinata (identified after dissolution of the calcareous outer layer by $\mathrm{HCl}$ treatment) differ from the description provided by Matsuoka et al. (1990) by the brown colour of the inner organic layer. The cysts of Diplopelta cf. symmetrica conform to the description of Dale et al. (1993) except for the central body diameter that can be up to $57 \mu \mathrm{m}$ in some specimens. The cysts of cf. Diplopelta sp. are spherical (30-37 $\mu \mathrm{m}$ in diameter), brown cysts that bear numerous hollow, hair-like processes between 2 and $5.6 \mu \mathrm{m}$ in length. Dubridinium cf. ulsterum corresponds to the description provided by Reid (1977) but is only slightly smaller in size (max. diameter of $44 \mu \mathrm{m})$. "Cyst type Cp", labelled "Cp" due to their resemblance with the cysts of Cochlodinium polykrikoides sensu $\mathrm{Li}$ et al. 2015, are large, subspherical to elongated cysts (max. height of up to $55 \mu \mathrm{m}$ ) with a thin, light brown cyst wall bearing $\sim 2 \mu$ m-high reticulate ornaments of a slightly darker brown shade. Cysts type $\mathrm{Cp}$ are larger and more elongated than C. polykrikoides cysts sensu Li et al. 2015. "Spiny brown type A" cysts (hereafter SBA) are relatively small, spherical (25-30 $\mu \mathrm{m}$ diameter) chorate cysts with smooth to microgranulated wall and numerous, long $(7-11 \mu \mathrm{m})$, apiculocavate, capitate processes. SBA may correspond to the cysts of Archaeperidinium bailongense reported from Pacific waters (Liu et al., 2015), but has a smaller central body diameter and a higher process length to cyst body diameter ratio. "Spiny brown type C" (hereafter SBC) has a spherical central body (25-34 $\mu \mathrm{m}$ diameter) with clearly visible microgranulations on the cyst wall; processes are numerous, 5 to $8 \mu \mathrm{m}$ in length, hollow, randomly distributed, and taper from a relatively large base (up to $2.5 \mu \mathrm{m}$ ) to an acuminate tip. SBC may be a morphotype of Echinidinium granulatum but was counted and analysed separately because of differences in process shape and trends in the timing of cyst production. "Spiny brown type D" (SBD) is a small (23-27 $\mu \mathrm{m}$ diameter including the periphragm), light brown cyst with a smooth wall and sparse, thin, usually erect but often bent, hollow, and acuminate processes 5-8 $\mu \mathrm{m}$ in length. Cysts of Protoperidinium sp. $\mathrm{C}$ are spherical, pale brown cysts with a loose, thin periphragm of variable height (max. of 4-7 $\mu \mathrm{m}$ ) surrounding the central body, and attached to the endophragm by numerous folds arranged in meandering lines. Cysts of Protoperidinium sp. C resemble the cysts of Protoperidinium parthenopes (Kawami and Matsuoka, 2009) but have a larger central body diameter $(34-45 \mu \mathrm{m})$, and thinner and more numerous folds connecting the two wall layers.

Several cyst taxa are grouped due to morphological similarities. In particular, Spiniferites bulloideus is grouped with Spiniferites ramosus, and Spiniferites hyperacanthus is grouped with Spiniferites mirabilis. Dubridinium caperatum and D. cf. ulsterum are grouped with Dubridinium spp., Echinidinium cf. delicatum is grouped with Echinidinium delicatum, the cysts of Protoperidinium nudum are grouped with Selenopemphix quanta. Both chordate and rhombic morphotypes of the cysts of Protoperidinium oblongum, together with Votadinium calvum, are grouped as the cysts of $P$. oblongum. Brigantedinium spp. include $B$. cariacoense, $B$. irregulare, B. majusculum and B. simplex as well as other smooth round brown cysts since archeopyles were not always visible due to unfavourable orientations or folding. Operculodinium centrocarpum sensu Wall and Dale 1966 includes both the morphotype described by Wall and Dale (1966) and the morphotype with "reduced processes". All dinoflagellate cysts identified in this study are listed in Table 1, along with their motile equivalents. Note that the expressions "autotrophic cyst" and "heterotrophic cyst" in the text refer to 
Table 1. List of dinoflagellate cyst taxa identified in the Cariaco sediment trap time series, and their motile equivalents (e.g., Zonneveld and Pospelova, 2015).

\begin{tabular}{|c|c|}
\hline $\begin{array}{l}\text { Dinoflagellate cyst } \\
\text { (Palaeontological name) }\end{array}$ & $\begin{array}{l}\text { Motile dinoflagellate } \\
\text { (Biological name) }\end{array}$ \\
\hline- & Archaeperidinium constrictum ${ }^{\mathrm{a}, *}$ \\
\hline- & cf. Biecheleria sp. ${ }^{\mathrm{a}, \mathrm{b}}$ \\
\hline Bitectatodinium spongium & Gonyaulacoid group \\
\hline Brigantedinium cariacoense & Protoperidinium avellanum \\
\hline Brigantedinium irregulare ${ }^{a}$ & Protoperidinium denticulatum \\
\hline Brigantedinium majusculum ${ }^{\mathrm{a}}$ & Protoperidinium sp. indet. \\
\hline Brigantedinium simplex & Protoperdinium conicoides \\
\hline Brigantedinium spp. & ?Protoperidinium spp. \\
\hline- & cf. Diplopelta sp. ${ }^{\mathrm{a}}$ \\
\hline- & Diplopelta cf. symmetrica ${ }^{\text {a }}$ \\
\hline Dubridinium caperatum ${ }^{\mathrm{a}, *}$ & Preperidinium meunieri \\
\hline Dubridinium cf. ulsterum $^{\mathrm{a}}$ & Diplopsalid group \\
\hline Dubridinium spp. ${ }^{\mathrm{a}}$ & Diplopsalid group \\
\hline Echinidinium aculeatum & Diplopsalid or Protoperidinioid group \\
\hline Echinidinium delicatum & Diplopsalid or Protoperidinioid group \\
\hline Echinidinium granulatum & Diplopsalid or Protoperidinioid group \\
\hline Echinidinium zonneveldiae $^{\mathrm{a}}$ & Diplopsalid or Protoperidinioid group \\
\hline Echinidinum cf. delicatum ${ }^{\mathrm{a}}$ & Diplopsalid or Protoperidinioid group \\
\hline Echinidinum spp.* & Diplopsalid or Protoperidinioid group \\
\hline- & cf. Ensiculifera carinata ${ }^{\text {a }}$ \\
\hline- & Gymnodinium nolleri $^{\mathrm{a}}$ \\
\hline Lejeunecysta marieae ${ }^{*}$ & Protoperidinioid group \\
\hline Lejeunecysta oliva ${ }^{*}$ & Protoperidinioid group \\
\hline ?Lejeunecysta sp. & Protoperidinioid group \\
\hline Lingulodinium machaerophorum ${ }^{*}$ & Lingulodinium polyedrum \\
\hline Operculodinium centrocarpum sensu Wall \& Dale $1966^{*}$ & Protoceratium reticulatum \\
\hline Operculodinium centrocarpum reduced processes* & Protoceratium reticulatum \\
\hline- & Pentapharsodinium dale ${ }^{*}$ \\
\hline- & Polykrikos kofoidii sensu Matsuoka et al. 2009 ${ }^{\mathrm{a}, *}$ \\
\hline Polysphaeridium zoharyi ${ }^{*}$ & Pyrodinium bahamense var. bahamense \\
\hline- & Protoperidinium americanum ${ }^{\mathrm{a}, *}$ \\
\hline- & Protoperidinium fukuyoi ${ }^{\text {a }}$ \\
\hline- & Protoperidinium nudum ${ }^{\mathrm{a}}$ \\
\hline- & $\begin{array}{l}\text { Protoperidinium oblongum (cordate cyst type sensu Wall \& } \\
\text { Dale 1968)* }\end{array}$ \\
\hline- & $\begin{array}{l}\text { Protoperidinium oblongum (rhombic cyst type sensu Wall \& } \\
\text { Dale 1968)* }\end{array}$ \\
\hline- & Protoperidinium stellatum \\
\hline- & Protoperidinium thulesense $^{\text {a }}$ \\
\hline- & Protoperidinium sp. $\mathrm{C}^{\mathrm{a}, *}$ \\
\hline Quinquecuspis concreta $*$ & Protoperidinium leonis \\
\hline Selenopemphix nephroides & Protoperidinium subinerme \\
\hline Selenopemphix quanta & Protoperidinium conicum \\
\hline Selenopemphix undulata ${ }^{\mathrm{a}}$ & Protoperidinium sp. indet. \\
\hline Spiniferites belerius ${ }^{\mathrm{a}}$ & Gonyaulax scrippsiae \\
\hline Spiniferites bentorii & Gonyaulax spinifera complex \\
\hline Spiniferites bulloideus & Gonyaulax spinifera complex \\
\hline Spiniferites hyperacanthus & Gonyaulax spinifera complex \\
\hline Spiniferites mirabilis & Gonyaulax spinifera complex \\
\hline Spiniferites ramosus & Gonyaulax spinifera complex \\
\hline Spiniferites spp.* & Gonyaulax spp. \\
\hline Stelladinium robustum ${ }^{\text {a }}$ & Protoperidinium sp. indet. \\
\hline Votadinium calvum ${ }^{*}$ & Protoperidinium oblongum \\
\hline Votadinium spinosum ${ }^{\mathrm{a}, *}$ & Protoperidinium claudicans \\
\hline
\end{tabular}


Table 1. Continued.

\begin{tabular}{|c|c|}
\hline $\begin{array}{l}\text { Dinoflagellate cyst } \\
\text { (Palaeontological name) }\end{array}$ & $\begin{array}{l}\text { Motile dinoflagellate } \\
\text { (Biological name) }\end{array}$ \\
\hline Cyst type $\mathrm{Cp}^{\mathrm{a}}$ & (Cochlodinium polykrikoides?) \\
\hline Cyst type $\mathrm{M} 1^{\mathrm{a}}{ }^{*}$ & Protoperidinium sp. indet. \\
\hline Spiny brown type $\mathrm{A}^{\mathrm{a}}$ & (Archaeperidinium bailongense?) \\
\hline Spiny brown type $C^{a}$ & ?Protoperidinium sp. indet. \\
\hline Spiny brown type $\mathrm{D}^{\mathrm{a}}$ & ?Protoperidinium $\mathrm{sp}$. indet. \\
\hline Spiny browns (other)* & ?Protoperidinoid group \\
\hline Protoperidinoids* & ?Protoperidinium spp. indet. \\
\hline Unknown cysts (heterotrophs) ${ }^{*}$ & - \\
\hline Unknown cysts (autotrophs)* & - \\
\hline Organic linings of calcareous dinoflagellate ${ }^{b}$ & - \\
\hline
\end{tabular}

a Taxa reported in the Cariaco Basin for the first time. ${ }^{\mathrm{b}}$ Taxa not included in cyst counts. ${ }^{*}$ Taxa never exceeding $1.5 \%$ of cyst assemblages.

cysts produced by autotrophic and heterotrophic dinoflagellates, respectively.

\subsection{Statistical analyses}

Multivariate analyses were used to investigate the relationships between individual dinoflagellate cyst taxa and both physico-chemical and biological parameters. Detrended canonical correspondence analyses (DCCA) and redundancy analyses (RDA) were performed on dinoflagellate cyst fluxes using CANOCO 4.5 for Windows (ter Braak and Šmilauer, 2002). Both types are direct gradient analyses, meaning that the ordination of "species" data (individual cyst taxa) in the multivariate space is further constrained to be a linear combination of the environmental (physico-chemical or biological) variables. Cyst taxa that never contributed more than $1.5 \%$ to the assemblages were excluded from the multivariate analyses to reduce noise.

DCCA were used first to determine the character of variability within the "species" data (cyst assemblages). A first DCCA of untransformed cyst data with physico-chemical parameters indicated a length of the first gradient of 2.34 standard deviations (SD). A second DCCA of square-root transformed cyst data with biological parameters resulted in a length of the first gradient of 1.76 SD. Being far smaller than $4 \mathrm{SD}$ in both cases, the gradients indicate a linear variation in the cyst data and justify the further use of RDA (Lepš and Šmilauer, 2003). Statistical significance of each environmental variable and ordination axis was determined using Monte Carlo tests based on 9999 permutations restricted for a time series data structure (Lepš and Šmilauer, 2003).

Physico-chemical variables were obtained primarily from the CARIACO program repository (www.imars.usf.edu/ cariaco). Measurement of water column parameters at $25 \mathrm{~m}$ depth (SST, SSS, $\sigma_{T}$, concentrations of $\mathrm{PO}_{4}, \mathrm{Si}(\mathrm{OH})_{4}$ and phaeopigments, and $\mathrm{C}: \mathrm{N}$ ratio of particulate organic matter), from monthly CTD casts and rosette sampling at the mooring site, were selected for the analyses. Chlorophyll $a$
(Chl a) measurements determined from rosette casts were integrated over the upper $100 \mathrm{~m}$ of the water column to better reflect primary production at the site. The mixed layer depth (MLD) is defined as the depth where the change in density $>0.125 \mathrm{~kg} \mathrm{~m}^{-3}$ (as in Pinckney et al., 2015; Claudia Benitez-Nelson, personal communication, 2016). Contents of bioSi, $\mathrm{C}_{\text {org }}, \mathrm{N}$, and $\mathrm{CaCO}_{3}$ refer to the parameters measured directly on sediment trap samples. Daily precipitation data were acquired from the GPCP Version 1.2 OneDegree Daily Precipitation Data Set (data set ds728.3, available from https://rda.ucar.edu; Huffman et al., 2016) and consist of daily precipitation estimates for two $1^{\circ}$ latitude $\times 1^{\circ}$ longitude boxes centred on $10.5^{\circ} \mathrm{N}, 65.5^{\circ} \mathrm{W}$ and $10.5^{\circ} \mathrm{N}$, $64.5^{\circ} \mathrm{W}$ (therefore covering all the Cariaco Basin area).

Biological variables, representing estimates for abundances of various planktonic groups, were determined from palynological data (this study), diatom and silicoflagellate census data from Romero et al. (2009), and HPLC photopigment data from Pinckney et al. (2015). In particular, fluxes of invertebrate mandibles, copepod eggs, ciliates, and microforaminiferal organic linings are derived from our palynological analyses. All other biological variables used in RDA (namely prasinophytes, cyanobacteria, cryptophytes, haptophytes, chlorophytes, diatoms, and "autotrophic dinoflagellates") are derived from HPLC pigment data as determined in Pinckney et al. (2015) and were integrated over the upper $100 \mathrm{~m}$. All physico-chemical and biological variables used in multivariate analyses are provided in the Supplement $(\mathrm{Ta}-$ ble S2).

\section{Results}

\subsection{Evolution of sea-surface parameters during the study period}

The seasonal cycle of upwelling that brings colder, nutrientrich waters to the surface and promotes primary produc- 
(a) Temperature (SST)

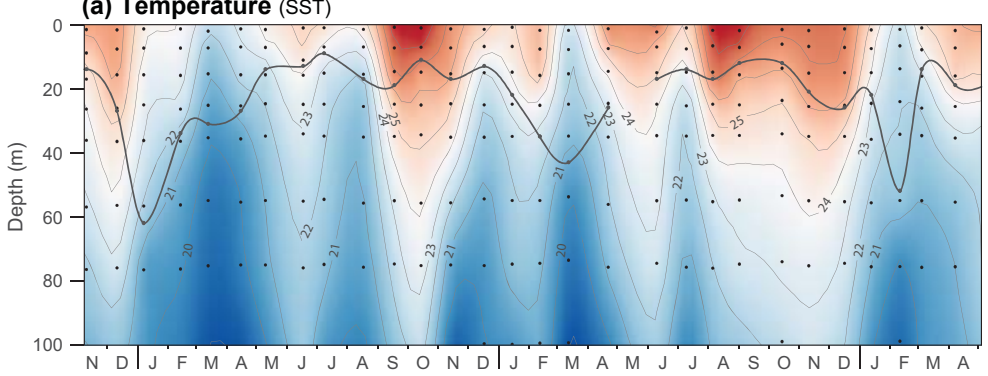

(b) Density $(q)$

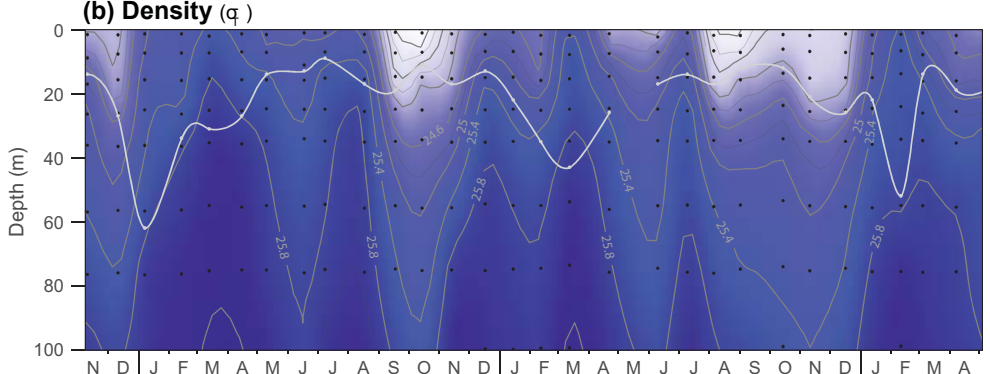

(c) Phosphate $\left(\mathrm{PO}_{4}\right)$

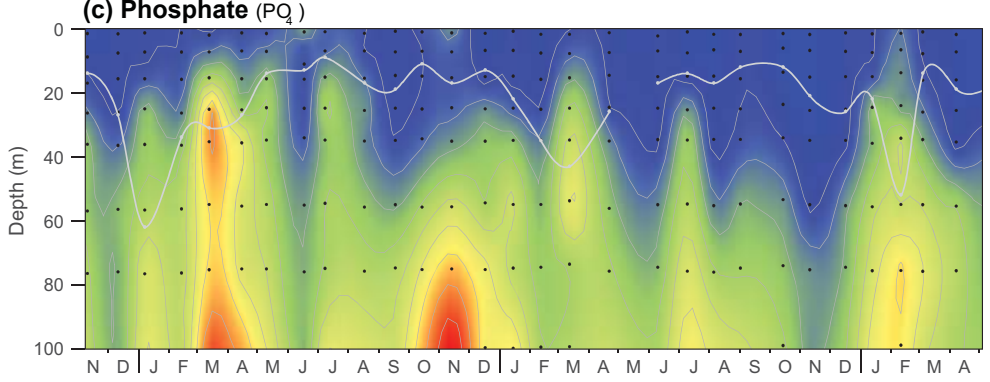

(d) Chlorophyll a $(\mathrm{Chl}$ a)

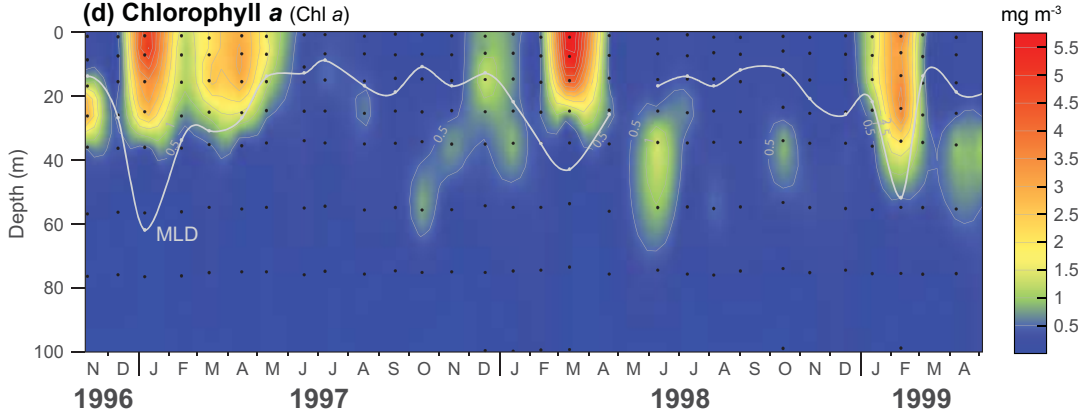

Figure 2. Contour plots of SST (a), $\sigma_{T}$ (b), $\mathrm{PO}_{4}(\mathbf{c})$, and $\mathrm{Chl} a$ (d) over the upper $100 \mathrm{~m}$ from monthly water column sampling at the CARIACO station. The grey (in a) or white (b-d) lines indicate the mixed layer depth (MLD).

tivity was well illustrated in the records of SST, $\sigma_{T}, \mathrm{PO}_{4}$, and $\mathrm{Chl} a$ during the study period (Fig. 2). In order to better characterize the variability in upwelling state and associated biological response, we define intervals of active (weak, moderate, and strong) and relaxed upwelling based on which isotherm reached a depth of $50 \mathrm{~m}$, determined from SST measurements at the study site (Fig. 2a). Conditions of "weak", "moderate", and "strong" upwelling correspond to intervals when the 22,21 , and $20^{\circ} \mathrm{C}$ isotherms reached $50 \mathrm{~m}$ depth, respectively. All other intervals (when SSTs at $50 \mathrm{~m}$ are $>22^{\circ} \mathrm{C}$ ) are considered to represent "relaxed" upwelling conditions. This practical definition is supported by previous observations in the basin (e.g., Müller-Karger et al., 2001; Astor et al., 2003; Goñi et al., 2003; Taylor et al., 2012).

During the 2.5 years of the time series, SSTs in the upper $100 \mathrm{~m}$ of the water column varied between $\sim 19$ and $28^{\circ} \mathrm{C}$, with lower temperatures at depth and generally during the upwelling season, and higher temperatures close to the surface during upwelling relaxation (Fig. 2a). The time series started with the end of upwelling relaxation of 1996, followed by a long interval of active upwelling conditions (January to May 1997) and a secondary upwelling event in July- 
August 1997. The upwelling was strongest in March 1997, leading to high levels of Chl $a$ sustained through May of that year (Fig. 2d). The following upwelling cycle started at the end of November 1997 and is more easily described as two "pulses" of weak to moderate upwelling ending in April 1998, with an additional shorter weak upwelling interval in July 1998. After an 6-month-long upwelling relaxation, weak upwelling conditions were observed again from mid-January to April 1999.

With SSS values varying only slightly (range of 36.5 to 37.0 over the top $100 \mathrm{~m}$; not shown), temperature was the primary driver of density change (Fig. 2b), with the lowest $\sigma_{T}$ values $\left(<24.6 \mathrm{~kg} \mathrm{~m}^{-3}\right)$ at the surface and strongest stratification (compressed isopycnals) observed during the warmest intervals in the record (November-December 1996, September-November 1997 and August-December 1998).

When nutrients were available above the mixed layer depth (see the example of phosphates in Fig. 2c), primary productivity was stimulated and elevated concentrations of Chl $a$ were observed (Fig. 2d). This was the case during most active upwelling intervals, with the exceptions of the JulyAugust 1997 upwelling event that apparently yielded very little Chl $a$ increase, and a few deep chlorophyll maxima, notably in June 1998 and April 1999.

\subsection{Main fluxes to the trap}

The main biogenic components of the sediment flux to the trap are shown in Fig. 3. Our time series spans $\sim 2.5$ years and was only interrupted by small gaps due to short lags between trap recovery and redeployments, and high primary productivity rates that caused Traps A and B to clog in April and May 1997 (Goñi et al., 2003). Fluxes of biogenic material shared the general pattern of total mass flux (Fig. 3a) but followed more closely the upwelling cycle than the total mass flux, which was also supplied by terrigenous material during the rainy (summer/fall) seasons. Mass fluxes of bioSi, $\mathrm{CaCO}_{3}$, and $\mathrm{C}_{\text {org }}$ generally increased under active upwelling conditions, with the highest values recorded during the upwelling events of 1997 and 1998 (up to $0.32 \mathrm{~g} \mathrm{~m}^{-2}$ day $^{-1}$ for bioSi and $\mathrm{CaCO}_{3}$, and $0.18 \mathrm{~g} \mathrm{~m}^{-2}$ day $^{-1}$ for $\mathrm{C}_{\text {org }}$ ). However, the weak upwelling of January-April 1999 constitutes a notable exception to this pattern, with some of the lowest fluxes of biogenic material in our record (Fig. 3a).

Diatom and silicoflagellate fluxes (data from Romero et al., 2009; Fig. 3b) showed very low abundances during upwelling relaxation. The record also showed only modest contributions during active upwelling intervals of 1996, 1997, and 1998. In contrast, the weak upwelling event of 1999 was marked by the highest fluxes of diatom valves and silicoflagellate skeletons of the record (up to 21.5 and $2.4 \times 10^{6}$ individuals $\mathrm{m}^{-2} \mathrm{day}^{-1}$, respectively).

The most abundant palynomorphs in the time series were ciliates, dinoflagellate cysts, invertebrate mandibles, motile dinoflagellates, copepod eggs, micro- (a) Mass fluxes

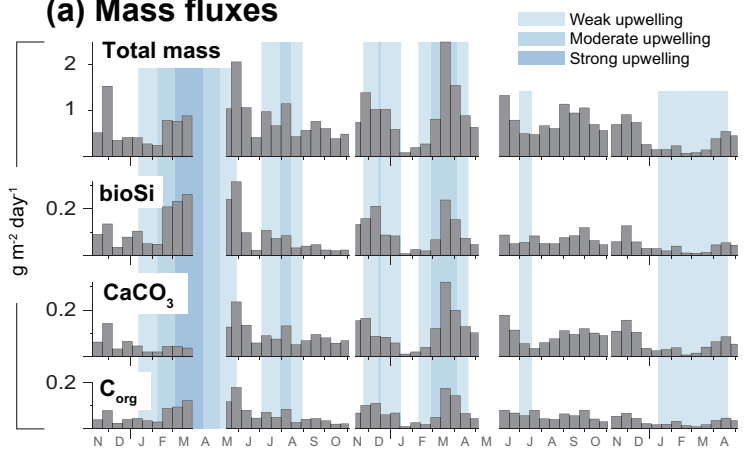

(b) Diatom \& silicoflagellate fluxes

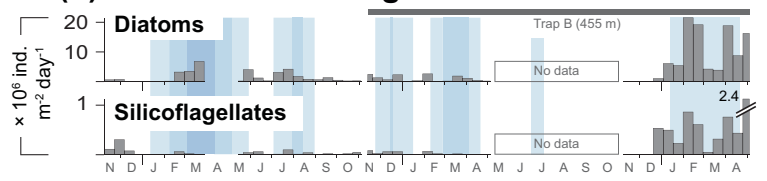

(c) Main palynomorph fluxes

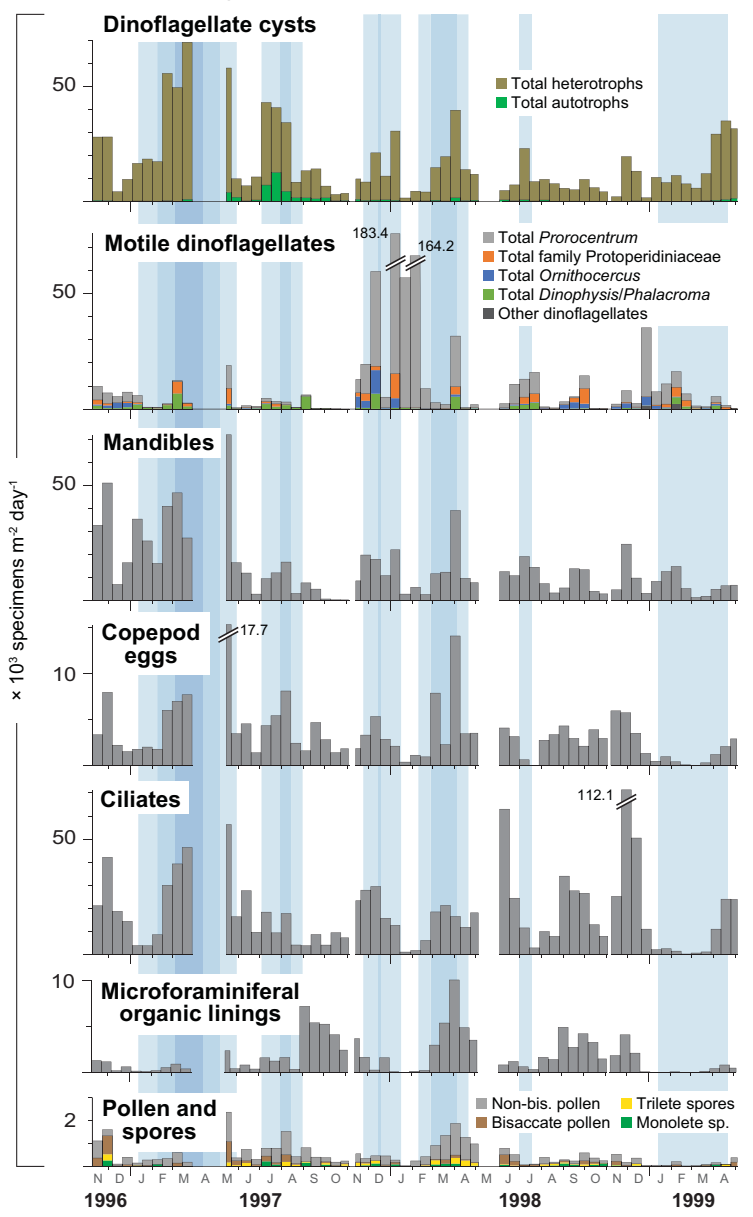

Figure 3. Main fluxes to the trap. (a) Fluxes of total sediment mass, biogenic silica, calcium carbonate, and organic carbon. (b) Diatom and silicoflagellate fluxes (from Romero et al., 2009). (c) Fluxes of the dominant groups of palynomorphs. Vertical blue shaded areas highlight intervals of active upwelling. Breaks in the horizontal axes indicate gaps in the time series. 


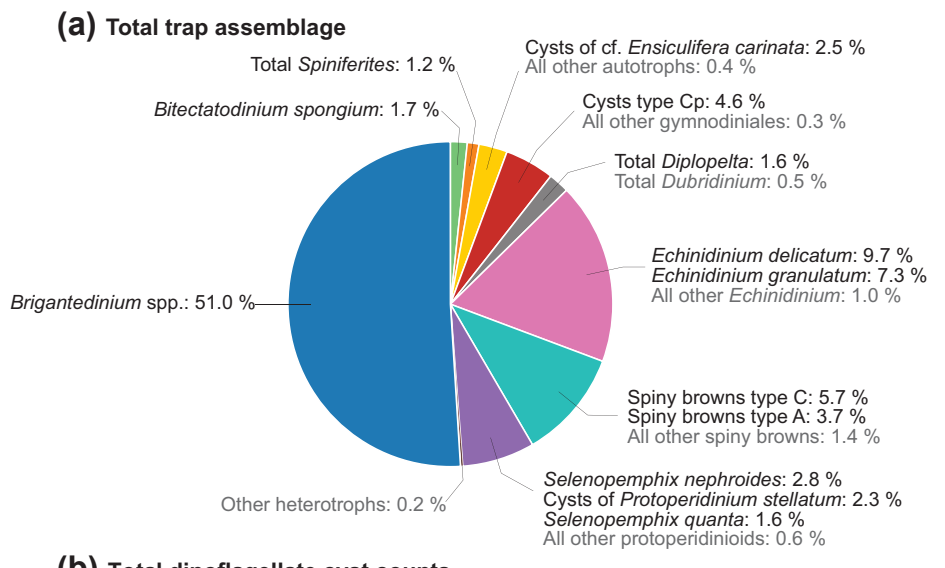

(b) Total dinoflagellate cyst counts

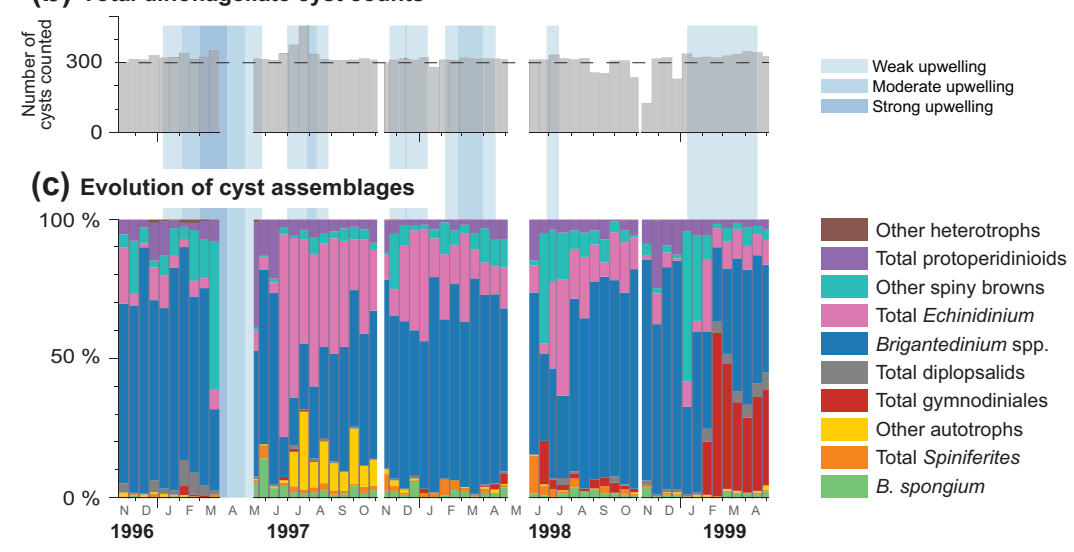

Figure 4. Dinoflagellate cyst assemblages in the Cariaco Basin over the $\sim 2.5$ years of the sediment trap time series. (a) Total trap assemblage. (b) Cyst counts per sample indicating the few samples $<300$ which should be interpreted with caution. (c) Contributions from the main groups of dinoflagellate cysts. Blue shaded areas indicate intervals of active upwelling, as in Fig. 3.

foraminiferal organic linings, and pollen and spores, with average fluxes of 18.6, 17.1, 14.1, 13.5, 3.4, 1.8 , and $0.5 \times 10^{3}$ specimens $\mathrm{m}^{-2} \mathrm{day}^{-1}$, respectively (Fig. 3c). Abundances of dinoflagellate cysts, overwhelmingly of heterotrophic affinity, varied between $1.6 \times 10^{3}$ cysts $^{-2} \mathrm{day}^{-1}$ during upwelling relaxation, and $69.2 \times 10^{3}$ cysts $^{-2}$ day $^{-1}$ under conditions of active upwelling. In fact, variations in cyst fluxes were tightly coupled with the state of upwelling, as described in more detail below (Sect. 4.3). Abundant motile dinoflagellates were also recovered in the sediment trap samples, and are reported in Fig. 3c at the genus or family level. Our record indicates that Dinophysis/Phalacroma species consistently occurred under active upwelling conditions, and even more prominently, Prorocentrum species (primarily $P$. compressum, $P$. micans and $P$. gracile) can form very large blooms, as observed in January-February 1998 (up to $183.4 \times 10^{3}$ cysts $^{-2}$ day $^{-1}$ ).

Mandibles and copepod eggs, both indicators of zooplankton abundance, showed generally higher fluxes during active upwelling intervals, with peak values recorded following moderate to strong upwelling events (Fig. 3c). Ciliates also seemed to respond positively to upwelling but showed markedly increased abundances during upwelling relaxation as well, especially in the summer and fall of 1998. Fluxes of micro-foraminiferal organic linings were generally under $2 \times 10^{3}$ linings $\mathrm{m}^{-2} \mathrm{day}^{-1}$, except for three 2-4-monthlong intervals, two of which occurred under relaxed upwelling conditions (summer/fall of 1997 and 1998). Pollen grains and spores, although routinely observed, rarely exceeded $1 \times 10^{3}$ grains $\mathrm{m}^{-2}$ day $^{-1}$ and thus formed only a minor component of the biogenic flux, which is consistent with previous studies that showed that the organic matter delivered to the shallow traps at the CARIACO station is overwhelmingly marine (e.g., Thunell et al., 2000; Goñi et al., 2003).

\subsection{Dinoflagellate cyst assemblages and fluxes}

Over the duration of the time series, the total trap assemblage is dominated by Brigantedinium spp. (51.0\%), accompanied by Echinidinium delicatum (9.7\%), Echinidinium granulatum (7.3\%), SBC (5.7\%), cyst type Cp (4.6\%), and SBA $(3.7 \%)$. All other cyst taxa account for less than $3 \%$ of the total assemblage (Fig. 4a). 
While Brigantedinium spp. dominate most assemblages in the time series (Fig. 4c), some intervals show a greater contribution of Echinidinium species and other spiny brown cysts (especially from June 1997 to January 1998), the cysts of cf. Ensiculifera carinata (mainly in June-October 1997) and gymnodinialeans (primarily cysts type $\mathrm{Cp}$ in FebruaryMay 1999). Cysts with cell content constituted on average $51.5 \%$ of the assemblages in each trap sample, with no particular change across seasons observed in individual cyst taxa records (Fig. 5).

Seasonal variations in dinoflagellate cyst production are illustrated in Fig. 5. Overall, most cyst taxa responded positively to upwelling strength, but some taxa in particular clearly showed increased fluxes during active upwelling intervals. Of those, Brigantedinium spp. showed the closest and more consistent response to upwelling strength, with higher fluxes (up to $35.2 \times 10^{3}$ cysts $^{-2}$ day $^{-1}$ ) recorded during all active upwelling intervals. The upwelling event of January-May 1997, the strongest in our record, resulted in the most pronounced increases in Brigantedinium spp., SBC, cysts of cf. Diplopelta sp., Dubridinium spp., Quinquecuspis concreta, Echinidinium spp., Selenopemphix quanta, and Selenopemphix nephroides (Fig. 5). The latter two taxa (S. quanta and S. nephroides) also showed high abundances during the secondary upwelling events of 1997 and 1998. Echinidinium delicatum and SBD showed increased fluxes during active upwelling intervals, particularly in the "pulse" of 1998. Spiniferites ramosus and Bitectatodinium spongium, both species produced by autotrophic dinoflagellates, generally responded positively to upwelling strength as well. Cysts type $\mathrm{Cp}$ were particularly abundant towards the end of the time series, during the weak upwelling event of 1999.

Some cyst taxa appeared to be associated with secondary upwelling events only. Echinidinium granulatum and the cysts of cf. E. carinata showed pronounced flux increases in July-August 1997, and fluxes of the cysts of Protoperidinium fukuyoi and Gymnodinium nolleri markedly increased in June-July 1998.

Another group of generally less abundant cyst taxa showed higher fluxes at the onset of active upwelling intervals; these include Echinidinium aculeatum, Stelladinium robustum, and SBA (Fig. 5). Notably, increases of cysts of Protoperidinium stellatum fluxes preceding active upwelling intervals by up to $\sim 1$ month were recorded 3 times over the time series, although its maximum abundance occurred at the end of the strong upwelling event of 1997.

\subsection{Cyst production vs. measured physico-chemical parameters $\left(\mathbf{R D A} \mathbf{e n v i}_{\text {en }}\right)$}

The seasonality of dinoflagellate cyst production was analysed in relation to physico-chemical parameters in the RDA

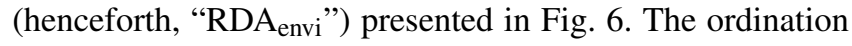
is significant as a whole $(p=0.007)$, with the first two RDA axes capturing 41.9 and $9.2 \%$ of the variance in species

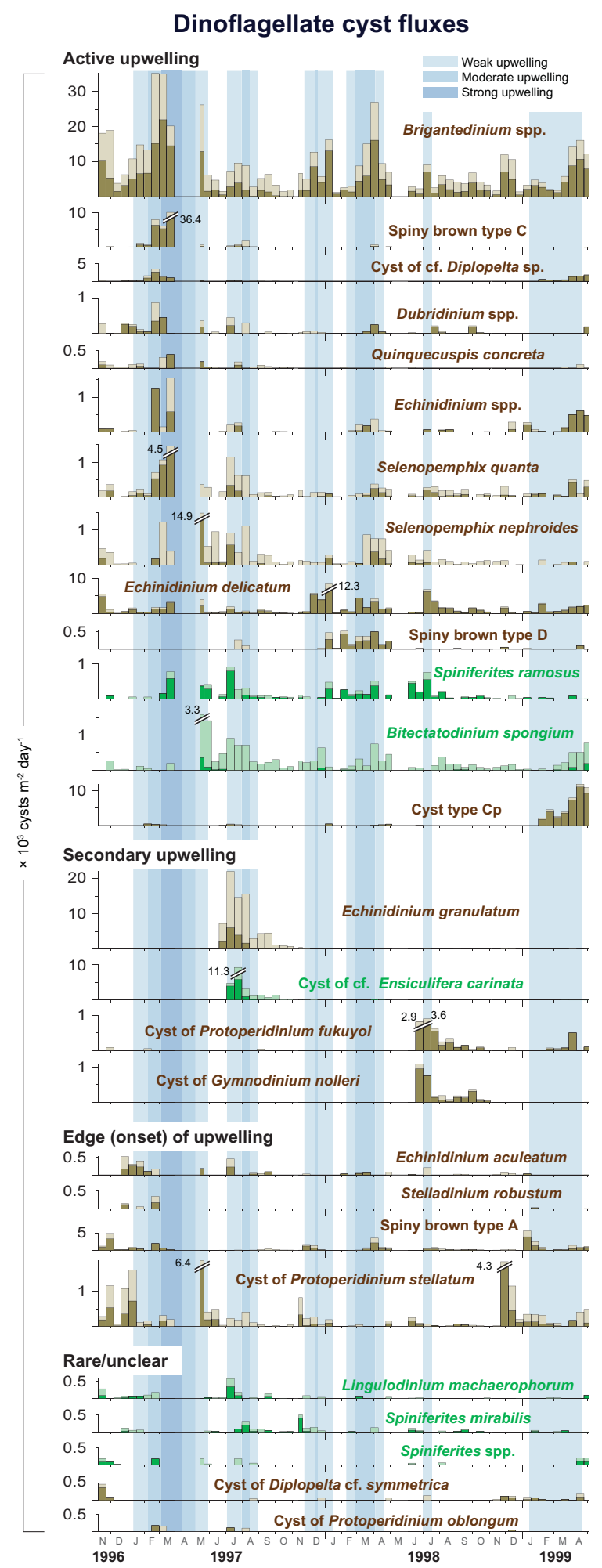

Figure 5. Fluxes of selected dinoflagellate cyst taxa in the sediment trap samples. Cyst taxa are organized in groups (active upwelling, secondary upwelling, edge (onset) of upwelling, and rare/unclear) based on their abundance patterns relative to upwelling intervals (indicated as blue shaded areas). Cyst taxa of autotrophic (heterotrophic) affinity are shown in green (brown), with darker shades indicating cysts with cell content. 

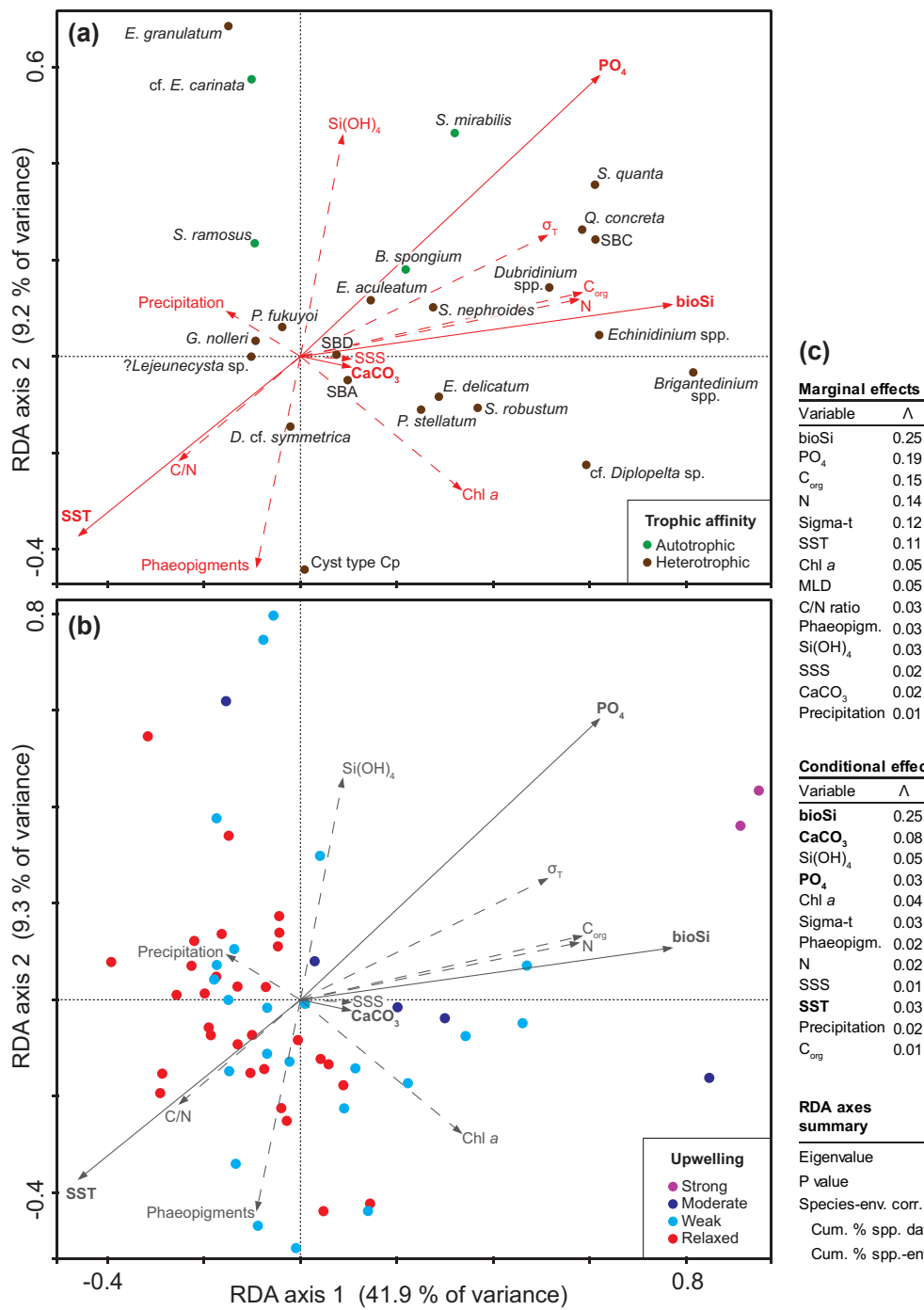

$\begin{array}{ll}\mathrm{C} / \mathrm{N} \text { ratio } & 0.05 \\ 0.03\end{array}$

Phaeopigm. 0.03

$\mathrm{Si}(\mathrm{OH})_{4} \quad 0.03$

SSS $\quad 0.02$

$\begin{array}{lr}\mathrm{CaCO}_{3} & 0.02 \\ \text { Precipitation } & 0.01\end{array}$

Conditional effects

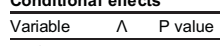

\begin{tabular}{lll}
\hline bioSi & 0.25 & $\mathbf{0 . 0 1 1}$ \\
Caco & 0.08 & $\mathbf{0 . 0 0 8}$
\end{tabular}

$\begin{array}{lll}\mathrm{CaCO}_{3} & 0.08 & \mathbf{0 . 0 0 8} \\ \mathrm{Si}(\mathrm{OH})_{4} & 0.05 & 0.183\end{array}$

$\begin{array}{lll}\mathrm{PO}_{4} & 0.03 & \mathbf{0 . 0 2 8}\end{array}$

$\begin{array}{lll}\text { Chl a } & 0.04 & 0.094 \\ \text { Sigma-t } & 0.03 & 0.136\end{array}$

$\begin{array}{lll}\text { Sigma-t } & 0.03 & 0.136 \\ & & 0.02\end{array}$

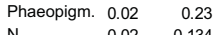

$\begin{array}{lrr}\mathrm{N} & 0.02 & 0.134 \\ \text { SSS } & 0.01 & 0.33\end{array}$

$\begin{array}{lll}\text { SST } & 0.03 & \mathbf{0 . 0 3 3}\end{array}$

Precipitation $0.02 \quad 0.075$

RDA axes RDA axis

\begin{tabular}{llll}
$\begin{array}{llll}\text { RDA axes } \\
\text { summary }\end{array}$ & \multicolumn{4}{l}{ RDA axis } \\
\cline { 2 - 5 } & Axis 1 & Axis 2 & Total \\
\hline Eigenvalue & 0.419 & 0.093 & 1.000
\end{tabular}

$\begin{array}{lllll}P \text { value } & \mathbf{0 . 0 0 7} & 0.204 & \mathbf{0 . 0 0 7}\end{array}$

Species-env. corr. $\quad 0.873 \quad 0.794$

Cum. \% spp. data $42.1 \quad 51.4$

Cum. \% spp.-env. $\quad 68.7 \quad 83.9$

Figure 6. Redundancy analysis (RDA) performed on dinoflagellate cyst fluxes using physico-chemical parameters as environmental variables $\left(\mathrm{RDA}_{\mathrm{envi}}\right)$. (a) Ordination of dinoflagellate cyst taxa and environmental variables. (b) Ordination of samples. (c) Marginal effects, conditional effects, and summary of axes statistics. Statistically significant variables and axes are shown as solid arrows and bold labels.

data (Fig. 6). The most important physico-chemical variables (significantly related to the dinoflagellate cyst data) are SST, bioSi, $\mathrm{PO}_{4}$, and $\mathrm{CaCO}_{3}$. The dominant gradient illustrated in the biplots is most easily described with regard to the state of upwelling. The lower left quadrant represents conditions of upwelling relaxation (with higher SST, lower nutrients, and bioSi), whereas the upper right quadrant (lower SST, higher nutrients and bioSi) corresponds to conditions of active upwelling. This interpretation is supported by the ordination of samples (Fig. 6b), which shows a clear distribution of samples along this gradient depending on the time of sediment collection.

The ordination of dinoflagellate cyst taxa along this gradient provides further evidence that Brigantedinium spp., $S$. quanta, SBC, Q. concreta, Echinidinium spp., and Dubridinium spp. are associated with conditions of active (strong) upwelling. Cyst taxa that showed higher abundances in active upwelling intervals other than the strong upwelling of 1997 , including secondary upwelling events, tend to be ordinated closer to the centroid. However, three cyst taxa have strong loadings along the $\mathrm{RDA}_{\mathrm{envi}}$ axis 2: E. granulatum and the cyst of cf. E. carinata (with strong positive scores) and cyst type $\mathrm{Cp}$ (strong negative score). Even though RDA axis 2 is not statistically significant (Fig. 6c), the ordination suggests an ecological niche that may be different, that is, less related to the strength of upwelling, for these three taxa.

\subsection{Cyst production vs. biological parameters $\left(\mathrm{RDA}_{\mathrm{bio}}\right)$}

Dinoflagellate cyst production was further investigated in the context of biological variables measured from water column and sediment trap sampling at the CARIACO station 


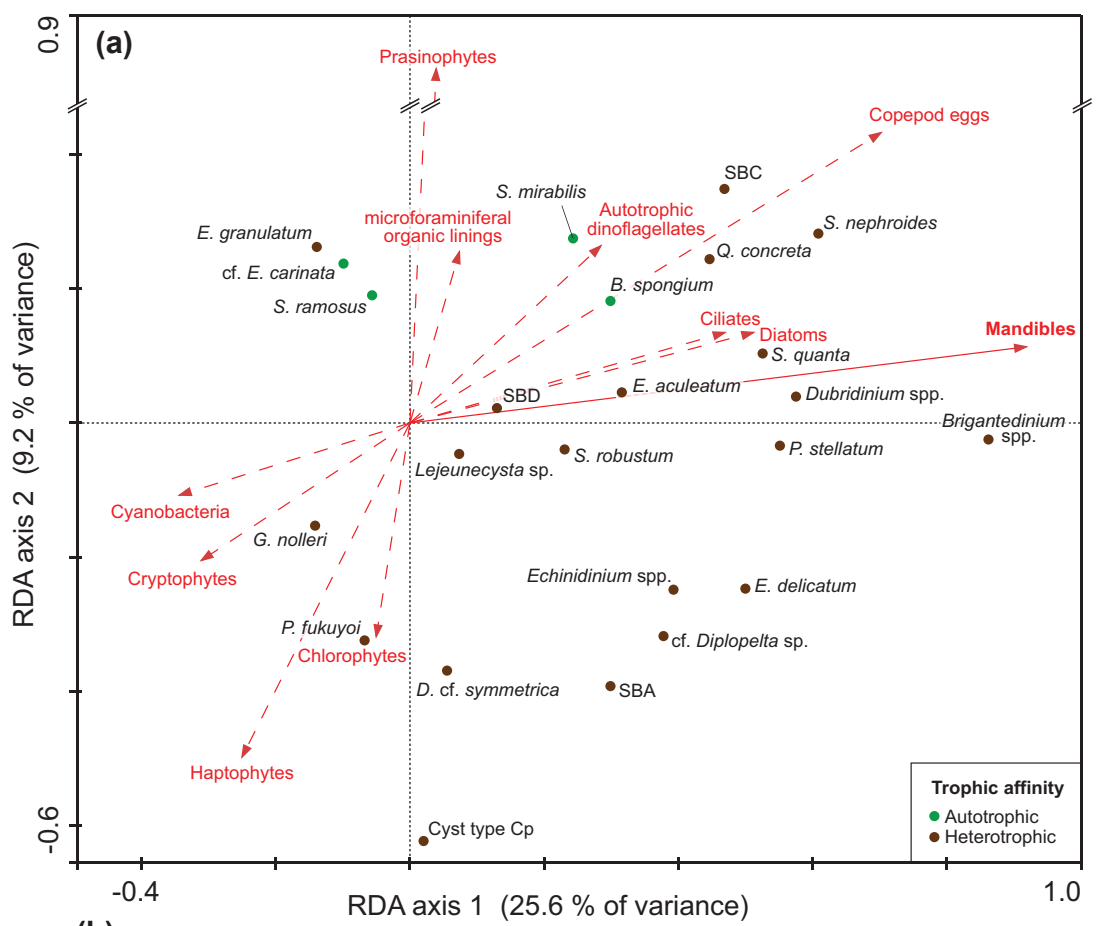

(b)

\begin{tabular}{lc}
\multicolumn{2}{l}{ Marginal effects } \\
\hline Variable & $\wedge$ \\
\hline Mandibles & 0.22 \\
Copepod eggs & 0.15 \\
Diatoms & 0.08 \\
Ciliates & 0.07 \\
Prasinophytes & 0.07 \\
Cyanobacteria & 0.06 \\
Cryptophytes & 0.05 \\
Haptophytes & 0.05 \\
Autotr. dinoflag. & 0.04 \\
Chlorophytes & 0.04 \\
Microforam. o.l. & 0.05
\end{tabular}

\begin{tabular}{lcr}
\multicolumn{3}{l}{ Conditional effe cts } \\
\hline Variable & $\wedge$ & Pvalue \\
\hline Mandibles & 0.22 & $\mathbf{0 . 0 1 1}$ \\
Prasinophytes & 0.07 & 0.216 \\
Cyanobacteria & 0.04 & 0.134 \\
Copepod eggs & 0.03 & 0.130 \\
Diatoms & 0.02 & 0.358 \\
Autotr. dinoflag. & 0.03 & 0.192 \\
Ciliates & 0.02 & 0.271 \\
Cryptophytes & 0.01 & 0.667 \\
Haptophytes & 0.03 & 0.371 \\
Microforam. o.l. & 0.01 & 0.358 \\
Chlorophytes & 0.01 & 0.779
\end{tabular}

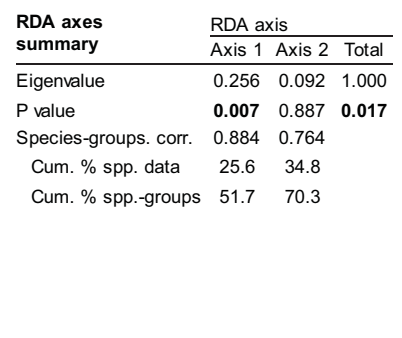

Figure 7. RDA of square-root-transformed dinoflagellate cyst fluxes, in the context of other major groups of the planktonic food web $\left(\mathrm{RDA}_{\mathrm{bio}}\right)$. (a) Ordination of cyst taxa and biological variables, obtained from palynological data (this study) and photopigment data (including "autotrophic dinoflagellates" and "diatoms", from Pinckney et al., 2015). (b) Marginal effects, conditional effects, and summary of RDA axes statistics. "Mandibles", the only statistically significant variable, is shown as a solid arrows with bold label.

(Fig. 7). This RDA ("RDA bio") was performed on squareroot-transformed dinoflagellate cyst fluxes in order to give more weight to less abundant cyst taxa. $\mathrm{RDA}_{\text {bio }}$ yields an ordination pattern of cyst taxa and significance levels similar to $\mathrm{RDA}_{\text {envi }}$, with the first two axes capturing 25.6 and $9.2 \%$ of the variance in the species data. Here too, both the first axis and the ordination as a whole are significant $(p=0.007)$, and the same underlying gradient of upwelling strength (bottomleft to top right: relaxed to active upwelling) is implied. Dinoflagellate cyst taxa previously found to be associated with active upwelling conditions (e.g., Brigantedinium spp., $S$. quanta and SBC) are ordinated close to indicators of diatom and zooplankton (mandibles and copepod eggs) abundance. Interestingly, the ordination along RDA axis 2 separates taxa such as E. granulatum, S. mirabilis and SBC on the positive side (positively correlated with prasinophytes), and the cysts of G. nolleri, P. fukuyoi, D. cf. symmetrica and cyst type Cp on the negative side, closer to chlorophytes, haptophytes, and cryptophytes (Fig. 7).

\section{Discussion}

This study presents the first record of dinoflagellate cyst production and seasonality in the Caribbean Sea, and sheds new light on dinoflagellate ecology in the context of their physico-chemical and biological environment. The dinoflagellate cyst sedimentary record of the basin has previously been studied by Wall (1967), González et al. (2008), and Mertens et al. (2009a) at multi-centennial to millennial resolution. While many dinoflagellate cyst taxa identified in our sediment trap time series were previously reported from those studies, many others (a total of 28, including types) are reported here for the first time (Table 1). Most of these 

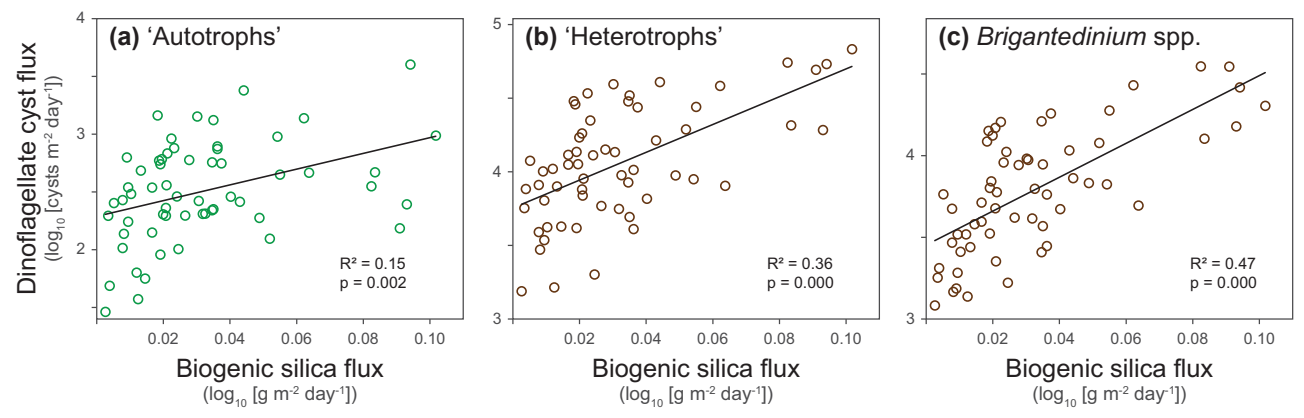

Figure 8. Relationships between biogenic silica flux and fluxes of autotrophic taxa (a), heterotrophic taxa (b), and Brigantedinium spp. (c) All fluxes are log-transformed and coefficients of determination $\left(R^{2}\right)$ are calculated after linear regressions.

"new" taxa are rare, lack clear taxonomic characterization (types), or were simply described after the above-mentioned studies were published. Conversely, a number of taxa previously reported in the basin (from sedimentary sequences that extend back to $\sim 73 \mathrm{ka}$ ) were not encountered in the time series, namely Achomosphaera sp., Ataxiodinium choane, Bitectatodinium tepikiense, Echinidinium euaxum, Echinidinium transparantum, several Impagidinium species (I. aculeatum, I. paradoxum, I. patulum, I. plicatum, I. sphaericum and I. strialatum), Islandinium minutum, Leipokatium invisitatum, Melitasphaeridium choanophorum, Nematosphaeropsis labyrinthus, Operculodinium israelianum, Selenopemphix selenoides, some Spiniferites species ( $S$. elongatus, $S$. lazus, S. membranaceus, S. pachydermus and S. scabratus), Tectatodinium pellitum, and Tuberculodinium vancampoae.

The Cariaco Basin sediment trap record shows that heterotrophic cyst taxa, particularly of the family Protoperidiniaceae, dominate the dinoflagellate cyst assemblages, consistently with studies from other upwelling systems (Zonneveld and Brummer, 2000; Susek et al., 2005; Ribeiro and Amorim, 2008; Pitcher and Joyce, 2009; Zonneveld et al., 2010; Bringué et al., 2013) or nutrient-rich regions without upwelling (e.g., Harland and Pudsey, 1999; Fujii and Matsuoka, 2006; Pospelova et al., 2010; Price and Pospelova, 2011). The Cariaco Basin is among the most productive systems in the world, with average cyst fluxes to the trap of $17.1 \times 10^{3}$ cysts $\mathrm{m}^{-2}$ day $^{-1}$. Cyst fluxes reported here are most similar to fluxes recorded in the NW Arabian Sea (Zonneveld and Brummer, 2000), about 1 order of magnitude higher than fluxes reported from a station located $\sim 370 \mathrm{~km}$ off Cap Blanc (Susek et al., 2005; Zonneveld et al., 2010), and about 2 orders of magnitude lower than a record from a near-shore station off Cape Columbine in the southern Benguela upwelling system (Pitcher and Joyce, 2009). When comparing records from the Cariaco Basin (this study) and the Santa Barbara Basin (Bringué et al., 2013), both sites characterized by seasonal upwelling, located at about the same distance from the nearest coast $(\sim 18 \mathrm{~km})$ and using the same cyst extraction technique, cyst fluxes are about 5 times lower in the Cariaco Basin than in the Santa Barbara Basin, where exceptionally high $\mathrm{C}_{\text {org }}$ fluxes are almost twice as high as in the Cariaco Basin (Thunell et al., 2007).

\subsection{Seasonality in dinoflagellate cyst production in the Cariaco Basin}

\subsubsection{The upwelling signal}

The upwelling signal is by far the clearest signal observed in the dinoflagellate cyst record. Most dinoflagellate cyst species show a marked positive response to upwelling strength (Figs. 3 and 5), an observation that is supported by multivariate analyses (Fig. 6). Increased cyst fluxes during intervals of active upwelling are observed for taxa of both autotrophic and heterotrophic affinities, suggesting that nutrient supply is the most limiting factor for both groups, whether the effect of nutrient limitation is expressed directly (for autotrophs) or indirectly (for heterotrophs).

Biogenic silica, most of which is precipitated by planktonic organisms in the surface layers, is commonly used as a proxy for diatom abundance in marine systems, even though silicoflagellates and radiolaria also contribute to the bioSi flux (e.g., Nelson et al., 1995; Ragueneau et al., 2000; Romero et al., 2009). Diatoms have been shown to dominate primary production and the bioSi flux in the Cariaco Basin, particularly during upwelling events (e.g., Thunell et al., 2000, 2008; Romero et al., 2009; Taylor et al., 2012; Pinckney et al., 2015). In our record, dinoflagellate cyst fluxes of both autotrophic and heterotrophic affinities correlated positively and significantly with bioSi fluxes (Fig. 8a and b), although the relationship is much clearer for heterotrophs $\left(R^{2}=0.36, p<0.001\right)$, and even stronger when considering only Brigantedinium spp. fluxes $\left(R^{2}=0.47, p<0.001\right.$; Fig. 8c). This is consistent with previous observations from other coastal marine settings (e.g., Fujii and Matsuoka, 2006; Zonneveld et al., 2010; Price and Pospelova, 2011; Bringué et al., 2013; Heikkilä et al., 2014) and confirm that fluxes of cysts of heterotrophic affinity (Brigantedinium spp. in particular) can be used as indicators of primary (mostly diatom) productivity in the Cariaco Basin. 
Diatom and silicoflagellate census data were also available for comparison with the cyst record, overlapping most of our time series (Romero et al., 2009). Even though diatom abundances tend to increase during active upwelling intervals, fluxes of diatom frustules and silicoflagellate skeletons do not match the bioSi record, largely because of discrepancies observed during the weak upwelling event of 1999 (Fig. 3b). Several factors may explain this apparent mismatch. Firstly, the samples used to generate diatom and silicoflagellate data were extracted from Trap A $(275 \mathrm{~m}$, same as this study) until November 1997, but from a deeper trap (Trap B, $455 \mathrm{~m}$ ) afterwards (Fig. 3b). However, it is unlikely that a difference in sedimentation between traps (e.g., by lateral advection of sediment at depth, or differences in trapping efficiency) played a role here since bioSi fluxes were also low in the Trap B record (Romero et al., 2009). Radiolaria fluxes were not quantified, and even modest numbers of those typically larger $(>150 \mu \mathrm{m})$ tests may also account for some discrepancies between the records. More importantly, the large increases in diatom fluxes recorded in 1999 are mainly attributable to small and/or weakly silicified species, namely Cyclotella litoralis and resting spores of Chaetoceros (Romero et al., 2009), which may not result in elevated mass fluxes of bioSi.

The fact that fluxes of heterotrophic dinoflagellate cysts are strongly, positively correlated with bioSi but not with fluxes of diatom frustules suggests that heterotrophic dinoflagellates respond more to total diatom biomass than to the availability of any particular diatom species in the Cariaco Basin. It is also possible that particles ballasted with bioSi, together with $\mathrm{CaCO}_{3}$-rich particles (also a significant variable in $\mathrm{RDA}_{\text {envi }}$; Fig. 6) facilitated the export of dinoflagellate cysts to the depths (the "ballast mineral" hypothesis; e.g., Thunell et al., 2007).

\subsubsection{Indicators of upwelling}

While nearly all dinoflagellate cyst taxa respond positively to upwelling in the system, the detailed response of each species varies depending on upwelling strength. In addition to Brigantedinium spp., several cyst taxa from the family Protoperidiniaceae are clearly associated with active upwelling (with the highest fluxes recorded during moderate to strong upwelling events), including $S$. quanta, $Q$. concreta and $S$. nephroides, which are known to have a particularly good relationship with diatoms (e.g., Jacobson and Anderson, 1986; Dale et al., 2002; Radi and de Vernal, 2008; Pospelova et al., 2008, 2010; Limoges et al., 2010; Price and Pospelova, 2011; Bringué et al., 2013, 2014). Our SBC type shows a clear preference for moderate to strong upwelling conditions as well (Fig. 5).

Two members of the subfamily Diplopsalioideae (Dubridinium spp. and cyst of cf. Diplopelta sp.) also seem to favour active upwelling conditions, although they tend to appear rather sporadically in the record and not only during active upwelling intervals (Fig. 5). Dubridinium caperatum, the most abundant Dubridinium species in our record, is usually found in highest abundances in the vicinity of active upwelling cells (e.g., Zonneveld et al., 2013). Other Dubridinium species tend to be abundant in coastal areas where food sources are diverse (e.g., Naustvoll, 2000), including in eutrophic and heavily polluted embayments (e.g., Matsuoka, 1999; Pospelova et al., 2005; Dale, 2009; Pospelova and Kim, 2010; Krepakevich and Pospelova, 2010). Our record suggests that these two diplopsalid taxa reflect active upwelling conditions in the Cariaco Basin.

Several "spiny brown" cysts (E. aculeatum, E. delicatum, E. granulatum, Echinidinium spp. and SBD) also show a strong association with active upwelling conditions, but they seem to respond more strongly to weaker upwelling conditions, with the highest fluxes recorded either at the onset or during weak or secondary upwelling events (Fig. 5). Many Echinidinium species are commonly found in upwelling regions worldwide (e.g., Zonneveld et al., 2013) and in a sediment trap study from the California Current upwelling system, fluxes of E. aculeatum, E. delicatum, and Echinidinium spp. were highest when upwelling was active but not at its strongest (Bringué et al., 2013). Echinidinium granulatum was observed during active upwelling in the Arabian Sea (Zonneveld and Brummer, 2000), but no clear link was observed off Cap Blanc, where it remained nonetheless associated with elevated nitrate and $\mathrm{C}_{\text {org }}$ concentrations (Zonneveld et al., 2010). Therefore, in the Cariaco Basin, these spiny brown taxa may be good indicators of weak to moderate upwelling conditions.

Three taxa of autotrophic affinity (B. spongium, S. ramosus and cyst of cf. E. carinata) also show higher abundances during active upwelling intervals (Fig. 5), likely as a direct response to nutrient loading. A common species in our record, B. spongium is known to thrive in warm (yearround SST $>20^{\circ} \mathrm{C}$ ), nutrient-rich environments (e.g., Zonneveld and Jurkschat, 1999; Zonneveld et al., 2013) and was also documented to produce cysts during times of active upwelling in sediment trap studies from the Somali Basin (NW Arabian Sea; Zonneveld and Brummer, 2000) and off Cap Blanc (NW Africa; Susek et al., 2005; Zonneveld et al., 2010). The detailed response of $S$. ramosus and cysts of cf. $E$. carinata to upwelling is less clear. Spiniferites ramosus is a cosmopolitan species (Zonneveld et al., 2013) with complex seasonal patterns that vary from site to site (Pospelova et al., 2018). In our record, S. ramosus shows no clear relationship to SST (Fig. 6) but responds to nutrient input, with modest increases in fluxes of cysts with cell content (i.e., recently produced and not yet excysted) recorded during almost all upwelling events, regardless of upwelling intensity or duration (Fig. 5). The single, large bloom of cf. E. carinata observed during the secondary upwelling event of 1997 (Fig. 5) occurred at a time when nutrients were available below a shallow MLD $(<20 \mathrm{~m})$, during an upwelling event that yielded very little Chl $a$ levels (Fig. 2). It has been suggested that 
environmental affinities of $E$. carinata are similar to those of Scrippsiella trochoidea with optimal SST range of 18$21^{\circ} \mathrm{C}$ (Shin et al., 2012), which would correspond to temperatures observed below $50 \mathrm{~m}$ during the July-August 1997 bloom. This may suggest a deeper habitat for cf. E. carinata in the Cariaco Basin, rather than a direct association with upwelling.

\subsection{Interactions between dinoflagellates and other major planktonic groups}

Marine food webs are complex trophic systems in which dinoflagellates interact with a variety of organisms, including components of the picoplankton, phytoplankton, and micro- to macrozooplankton. Autotrophic dinoflagellates, as primary producers, compete for resources (nutrients) with other phytoplankton groups (diatoms, haptophytes, chlorophytes, and so forth). Diatoms typically dominate primary production in upwelling systems, including in the Cariaco Basin (e.g., Romero et al., 2009; Pinckney et al., 2015), while autotrophic dinoflagellates and haptophytes are generally thought to be more abundant during, or at the transition to, upwelling relaxation (e.g., Goñi et al., 2003; Smayda and Trainer, 2010; Bringué et al., 2013). In a study of the Si cycle and $\mathrm{Si}: \mathrm{C}: \mathrm{N}$ ratios of sinking particles in the Cariaco Basin, Thunell et al. (2008) demonstrated that silicic acid (a macronutrient essential for diatom growth but not used by dinoflagellates) is the limiting nutrient in the upper $50 \mathrm{~m}$ of the water column during active upwelling, whereas nitrates limit primary production in summer/fall. In our record, autotrophic dinoflagellates (cysts and motiles alike) do not appear to compete with diatom for resources, as both groups respond positively to upwelling (Figs. 3 and 5), and fluxes of autotrophic cysts and bioSi are positively correlated (Fig. 8). This is consistent with silicic acid limiting diatom production during active upwelling, and nitrate limitation affecting both diatoms and autotrophic dinoflagellates during upwelling relaxation.

Heterotrophic (and mixotrophic) dinoflagellates exert a significant, if not dominant, grazing impact on upwelling and other productive ecosystems (Jeong, 1999; Sherr and Sherr, 2007; Calbet, 2008). Besides their role as grazers on phytoplankton, they can also prey on copepod eggs and early naupliar stages, and serve as prey for meso- to macrozooplankton or for other dinoflagellates (e.g., Jeong, 1999; Jeong et al., 2010). In a sediment trap study off Cap Blanc, Zonneveld et al. (2010) investigated the potential food sources of heterotrophic dinoflagellates using diatom census data and measurements of bioSi, $\mathrm{C}_{\text {org }}$, and $\mathrm{CaCO}_{3}$. They observed a significant relationship between cyst and total diatom valves accumulation rates, including for Brigantedinium spp. and $S$. quanta, as well as several protoperidinioid cyst taxa possibly associated with haptophytes (suggested by a correlation with $\mathrm{CaCO}_{3}$ fluxes), including $P$. stellatum. In this study, potential interactions between heterotrophic dinoflagellates and other important planktonic groups are investigated using $\mathrm{RDA}_{\text {bio }}$ (Fig. 7) and by comparing cyst fluxes with photopigment data of Pinckney et al. (2015). As discussed above, most of the abundant heterotrophic cyst taxa are directly associated with active upwelling conditions, when diatoms dominate primary production. Not surprisingly, indicators of zooplankton abundance (mandibles and copepod eggs) are ordinated close to the "active upwelling pole" of the implied gradient in the $\mathrm{RDA}_{\text {bio }}$ biplot (upper right quadrant in Fig. 7), together with diatoms. However, this only suggests co-occurrence and we cannot comment further on causal (trophic) relationships.

Several other heterotrophic cyst taxa in the record show increased abundances that do not appear to be directly related to diatom availability. Cysts of $P$. stellatum show repeated increases in abundance during upwelling relaxation, generally within $\sim 1$ month of upwelling onset (Fig. 5). Interestingly, two of the pronounced increases in P. stellatum cysts occur at times when haptophytes (including coccolithophorids) were recorded in relatively large quantities in the water column (Pinckney et al., 2015). In a similar manner than in Zonneveld et al. (2010), P. stellatum is ordinated close to $\mathrm{CaCO}_{3}$ as in $\mathrm{RDA}_{\text {envi }}$ (Fig. 6), even though $\mathrm{CaCO}_{3}$ is not clearly related to haptophyte productivity in the basin (Goñi et al., 2009). Despite the absence of an increase in P. stellatum cyst flux during the May-July 1998 subsurface bloom of coccolithophes (Pinckney et al., 2015), there is growing evidence that haptophytes may serve as a food source for $P$. stellatum (Zonneveld et al., 2010).

The only noticeable increases in fluxes of cysts of $P$. fukuyoi and G. nolleri took place during the short secondary upwelling event of July 1998 (Fig. 5). These increases follow a peak in ciliate fluxes (Fig. 3) and occurred at a time when coccolithophores, cryptophytes, and chlorophytes were abundant below the MLD; prasinophytes were also present but in lower abundances than during most of the record (Pinckney et al., 2015). In RDA bio, the cysts of $P$. fukuyoi and $G$. nolleri are ordinated in the same quadrant (lower left) as haptophytes, cryptophytes and, chlorophytes (Fig. 7). Although these organisms were also abundant at other times in our record, their co-occurrence suggests possible trophic relationships, and the fact that all those potential food sources were present only below the MLD may suggest that $P$. fukuyoi and G. nolleri may dwell in, or access, deeper waters. Interestingly, higher fluxes of cysts of $P$. fukuyoi were also recorded in the Santa Barbara Basin under similar circumstances, when a short secondary upwelling pulse interrupted relaxed upwelling conditions (Bringué et al., 2013). Other sediment trap records of $P$. fukuyoi cyst production from the Strait of Georgia (Pospelova et al., 2010) and Saanich Inlet (Price and Pospelova, 2011) in the productive waters of coastal southwestern Canada also indicate higher fluxes during the warmest months of the year (Mertens et al., 2013).

Echinidinium granulatum also showed a single interval with marked increased abundances, during the secondary upwelling event of July-August 1997 (Fig. 5). Of the available 
data, the only planktonic groups that were noticeably abundant at this time were diatoms (mostly $C$. litoralis; Romero et al., 2009) and prasinophytes, which may act as food sources for E. granulatum.

Cysts type $\mathrm{Cp}$ (possibly the cysts of Cochlodinium polykrikoides sensu $\mathrm{Li}$ et al. 2015) have a strong negative loading along $\mathrm{RDA}_{\text {bio }}$ axis 2 with no obvious link with other planktonic groups (Fig. 7). This taxon was observed almost exclusively at the end of the time series, during the weak upwelling event of 1999 which resulted in modestly elevated Chl $a$ concentrations (Fig. 2) and large fluxes of (mostly small or weakly silicified) diatom frustules and silicoflagellates that were, however, not reflected in the bioSi record (Fig. 3). One of the major species responsible for harmful algal blooms, $C$. polykrikoides exhibits a wide range of temperatures over which it can survive, and SST conditions in the Cariaco Basin fall within its optimal range (e.g., Matsuoka and Iwataki, 2004; Kudela and Gobler, 2012). Increases in cysts type $\mathrm{Cp}$ fluxes during that event is similar in timing and magnitude to that of Brigantedinium spp., the dominant cyst taxa in our record, but the exact factor(s) behind such a large increase in cyst type $\mathrm{Cp}$ abundances remains unclear.

\subsection{Effect of NAO and ENSO on dinoflagellates}

The NOA and ENSO phenomena have been documented to modulate precipitation in the Caribbean, and El Niño events may influence the basin's hydrography with a 1-year lag (e.g., Enfield and Mayer, 1997; Giannini et al., 2001; Astor et al., 2013). Summarizing observations at the CARIACO station over 14 years, Taylor et al. (2012) found only modest correlations between, on one hand, NAO and ENSO (with 1-year lag) indices, and hydrographical and biological measurements in the basin. Romero et al. (2009) reported a major change in the composition of diatom assemblages coeval with the 1997/98 ENSO event, with lower diatom production compared to the previous year and an increase in the relative contribution of pelagic species more commonly found in Caribbean surface waters.

Over the duration of our time series, a direct comparison (i.e., with no time lag applied) of the NAO index and Multivariate ENSO Index (MEI) to SST measurements yielded significant but weak negative correlations (Pearson's $r=-0.33, p=0.011$ for NAO; $r=-0.28, p=0.031$ for MEI). Visual examination of variations in dinoflagellate cyst production does not reveal any apparent link with NAO and ENSO (Fig. 9). Numerically, total dinoflagellate cyst fluxes and total heterotrophic cyst fluxes show significant but weak positive correlations with the NAO index $(r=0.33$, $p=0.010$ and $r=0.34, p=0.008$, respectively), while total autotrophic cyst fluxes are significantly but weakly correlated with MEI ( $r=0.40, p=0.002)$. Thus, there is little evidence for any "direct" (with no time lag) influence of NAO or ENSO on dinoflagellate cyst production in the basin.

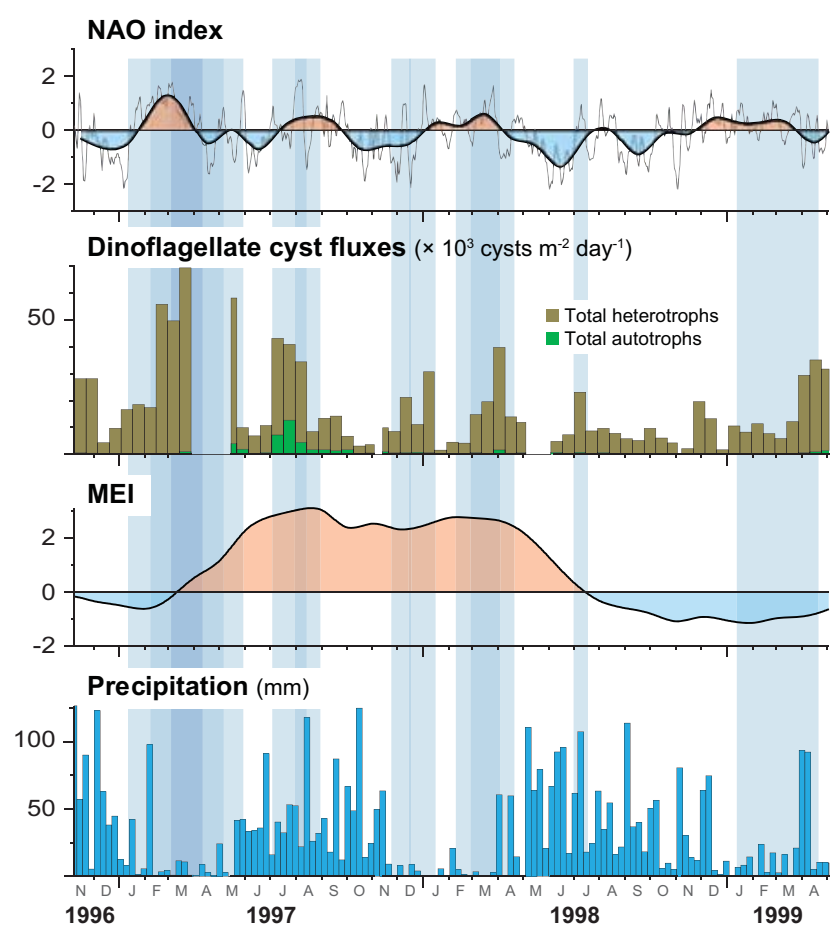

Figure 9. Comparison of dinoflagellate cyst fluxes to the trap with the North Atlantic Oscillation (NAO) index, the Multivariate ENSO Index (MEI) and weekly precipitation over the Cariaco Basin. The NAO index is shown as daily values (thin grey line) and monthly averages (thick black line), while MEI is drawn from monthly values. Blue shaded areas highlight active upwelling intervals, as in previous figures.

However, our record suggests that the 1997/98 El Niño event was rather expressed with a 1-year lag in the basin, with total cyst fluxes of the year 1999 being the lowest recorded between 1996 and 2009 (Fig. 9; Bringué, Thunell and Pospelova, unpublished data). A 1-year delay in ENSO effects has been observed for precipitation and SST patterns in the Caribbean (with dryer summers on the year of an El Niño event and wetter conditions the following summer; Enfield and Mayer, 1997; Giannini et al., 2001; Fig. 9) and consistent with observations at the CARIACO station (e.g., Müller-Karger, 2004; Taylor et al., 2012). A similar "damping" effect was observed in the Santa Barbara Basin, where the strong 1997/98 El Niño event hampered upwelling and resulted in greatly reduced primary production (e.g., Lange et al., 2000; Shipe et al., 2002).

The dinoflagellate cyst response to the 1997/98 El Niño event was also documented in the Strait of Georgia, (BC, Canada) by Pospelova et al. (2010). At this location, positive SST anomalies in the region and low snow accumulation over the Frasier River watershed associated with the 1997/98 El Niño winter (e.g., Foreman et al., 2001) resulted in higher SST and SSS conditions in the strait in the spring of 1998, and fluxes of cysts produced by some autotrophic 
taxa (including Spiniferites spp. and the cysts of $P$. dalei) and several heterotrophic taxa (E. delicatum, Echinidinium spp., S. nephroides, S. quanta, and the cysts of P. fukuyoi-as "cyst type A"), benefitting from an early start of their production season, were higher than in 1996 and 1997 (Pospelova et al., 2010). Apart from the fact that the time lag between ENSO events and their influence on the Cariaco Basin may be longer (about a year; e.g., Enfield and Mayer, 1997; Giannini et al., 2001) than on the Strait of Georgia (likely between $\sim 4$ and 10 months; e.g., Bograd and Lynn, 2001; Royer, 2005), the contrasting environmental settings between the two sites likely explains the very different response in dinoflagellate cyst production to the strong 1997/98 El Niño event. While cyst production of many dinoflagellates appear to have been promoted in the Strait of Georgia by a longer production season, weaker upwelling in the Cariaco Basin in 1998 and 1999 (compared to 1997) resulted in lower total cyst fluxes (Fig. 9). However, the unusually high production of cysts type Cp in February-May 1999 may be related to delayed effects of this strong 1997/98 El Niño event, although the exact mechanism remains unknown. Clearly, longer time series are needed to properly investigate ENSO effects in the basin and interannual variability in general.

\section{Conclusions}

This study documents dinoflagellate cyst production in the Cariaco Basin over a period of $\sim 2.5$ years. The sediment trap record shows that the basin harboured very diverse and abundant communities of cyst-producing dinoflagellates, with over 60 morphotypes identified (including $\sim 30$ reported in the basin for the first time) and cyst fluxes averaging $17.1 \times 10^{3}$ cysts $\mathrm{m}^{-2} \mathrm{day}^{-1}$, and up to $69.2 \times 10^{3}$ cysts $^{-2}$ day $^{-1}$ under active upwelling conditions.

In the basin, dinoflagellate cyst associations were dominated by cysts of heterotrophic affinity, particularly Brigantedinium spp. which alone accounted for over half the total trap assemblage. The seasonality in dinoflagellate cyst production strongly reflects variations in upwelling strength, with increases in cyst fluxes observed during active upwelling intervals. Fluxes of heterotrophic dinoflagellate cysts showed a strong positive correlation with biogenic silica but not with fluxes of diatom frustules, indicating that heterotrophic dinoflagellates responded more to total diatom biomass than to the availability of any particular species.

Dinoflagellate cyst taxa clearly associated with active upwelling conditions include Brigantedinium spp., Selenopemphix quanta, Selenopemphix nephroides, Quinquecuspis concreta, and Dubridinium spp. Cyst taxa of autotrophic affinity also responded positively to nutrient loading during active upwelling, with Bitectatodinium spongium showing the clearest response. Several "spiny brown" cysts, including E. aculeatum, E. delicatum, E. granulatum, and Echini- dinium spp. showed a closer affinity to weaker upwelling conditions.

New insights into possible trophic interactions are provided by comparing dinoflagellate cyst production with abundances of other major components of the planktonic food web at the CARIACO station. Autotrophic dinoflagellates did not appear to compete for resources (nutrients) with diatoms in the basin, as silicic acid limits diatom production during active upwelling intervals. Zooplankton abundance indicators (mandibles and copepod eggs) co-occurred with cyst taxa associated with active upwelling conditions (mostly protoperidiniaceans), when diatom productivity was high. In particular, the production of Protoperidinium stellatum cysts may be associated with haptophytes and/or $\mathrm{CaCO}_{3}$ fluxes. The bulk of Protoperidinium fukuyoi and Gymnodinium nolleri cyst production took place during a short secondary upwelling event that was marked by high abundances of coccolithophores, cryptophytes, and chlorophytes, suggesting that these groups may serve as food sources for $P$. fukuyoi and $G$. nolleri.

On interannual timescales, dinoflagellate cyst production seemed to be influenced by the strong 1997/98 El Niño event, with a 1-year lag. While seasonal variations associated with upwelling constitutes the dominant signal in the cyst record, interannual variability is also considerable and longer time series are needed in order to fully understand the environmental controls on dinoflagellate cyst production. Nevertheless, this work expands our knowledge of cyst-producing dinoflagellate ecology, helping the interpretation of fossil assemblages from the basin's sedimentary record and worldwide.

Data availability. Research data produced and used in this article are provided in the Supplement.

\section{Information about the Supplement}

The Supplement provided with this article includes total dinoflagellate cyst fluxes and cyst counts (Table S1), as well as all physico-chemical and biological variables used in analyses (Table S2).

\section{The Supplement related to this article is available online at https://doi.org/10.5194/bg-15-2325-2018-supplement.}

Author contributions. MB, RCT, and VP designed the project. RCT and ET organized and performed sediment trap deployments, and generated geochemical data on trap samples. VP provided lab equipment (and consumables) for the palynological treatment of samples. JLP and OER provided photopigment and siliceous microfossil data, respectively. MB selected, split, processed, and counted 
all samples, analysed the data, generated all figures, and wrote the manuscript. VP, RCT, OER, and JLP edited the manuscript.

Competing interests. The authors declare that they have no conflict of interest.

Acknowledgements. This work was funded by a Natural Sciences and Engineering Research Council of Canada (NSERC) Postdoctoral Fellowship (PDF) and an Advanced Support Program for Innovative Research Excellence (ASPIRE I - Track IIb) from the U. of South Carolina to Manuel Bringué, and an NSERC Discovery grant to Vera Pospelova. The CARIACO sediment trapping program was supported by the National Science Foundation (NSF; grants OCE 9401537, OCE 9729697, and OCE 1258991). The authors wish to thank Claudia Benitez-Nelson (University of South Carolina) for providing mixed layer depth data and for helpful discussions on the hydrology of the basin. Kenneth Mertens (IFREMER - Concarneau) is kindly thanked for his help in dinoflagellate cyst identification. The crew of the R/V Hermano Gines is also gratefully acknowledged for all operations at sea. The authors are grateful to Barrie Dale (University of Oslo), Sofia Ribeiro (Geological Survey of Denmark and Greenland), and the anonymous reviewer for their helpful and constructive comments that helped improve the manuscript. NRCan Contribution number: 20180015.

Edited by: Markus Kienast

Reviewed by: Barrie Dale, Sofia Ribeiro, and one anonymous referee

\section{References}

Alvera-Azcárate, A., Barth, A., and Weisberg, R. H.: A nested model of the Cariaco Basin (Venezuela): description of the basin's interior hydrography and interactions with the open ocean, Ocean Dynam., 59, 97-120, https://doi.org/10.1007/s10236-008-0169-y, 2009.

Antoine, D., André, J. M., and Morel, A.: Oceanic primary production. 2. Estimation at global scale from satellite (coastal zone color scanner) chlorophyll, Global Biogeochem. Cy., 10, 57-69, https://doi.org/10.1029/95gb02832, 1996.

Astor, Y., Müller-Karger, F., and Scranton, M. I.: Seasonal and interannual variation in the hydrography of the Cariaco Basin: Implications for basin ventilation, Cont. Shelf Res., 23, 125-144, https://doi.org/10.1016/s0278-4343(02)00130-9, 2003.

Astor, Y. M., Lorenzoni, L., Thunell, R., Varela, R., Müller-Karger, F., Troccoli, L., Taylor, G. T., Scranton, M. I., Tappa, E., and Rueda, D.: Interannual variability in sea surface temperature and $\mathrm{fCO}_{2}$ changes in the Cariaco Basin, Deep-Sea Res. Pt. II, 93, 33-43, https://doi.org/10.1016/j.dsr2.2013.01.002, 2013.

Black, D. E., Peterson, L. C., Overpeck, J. T., Kaplan, A., Evans, M. N., and Kashgarian, M.: Eight centuries of North Atlantic ocean atmosphere variability, Science, 286, 1709-1713, https://doi.org/10.1126/science.286.5445.1709, 1999.

Black, D. E., Abahazi, M. A., Thunell, R. C., Kaplan, A., Tappa, E. J., and Peterson, L. C.: An 8-century tropical Atlantic SST record from the Cariaco Basin: Baseline variability, twentieth-century warming, and Atlantic hurricane frequency, Paleoceanography, 22, PA4204, https://doi.org/10.1029/2007pa001427, 2007.

Bograd, S. J. and Lynn, R. J.: Physical-biological coupling in the California Current during the 1997-99 El Niño-La Niña cycle, Geophys. Res. Lett., 28, 275-278, https://doi.org/10.1029/2000g1012047, 2001.

Bout-Roumazeilles, V., Riboulleau, A., du Chatelet, E. A., Lorenzoni, L., Tribovillard, N., Murray, R. W., Müller-Karger, F., and Astor, Y. M.: Clay mineralogy of surface sediments as a tool for deciphering river contributions to the Cariaco Basin (Venezuela), J. Geophys. Res.-Oceans, 118, 750-761, https://doi.org/10.1002/jgrc.20079, 2013.

Bringué, M., Pospelova, V., and Pak, D.: Seasonal production of organic-walled dinoflagellate cysts in an upwelling system: A sediment trap study from the Santa Barbara Basin, California, Mar. Micropaleontol., 100, 34-51, https://doi.org/10.1016/j.marmicro.2013.03.007, 2013.

Bringué, M., Pospelova, V., and Field, D. B.: High resolution sedimentary record of dinoflagellate cysts reflects decadal variability and 20th century warming in the Santa Barbara Basin, Quaternary Sci. Rev., 105, 86-101, https://doi.org/10.1016/j.quascirev.2014.09.022, 2014.

Bringué, M., Pospelova, V., Calvert, S. E., Enkin, R. J., Lacourse, T., and Ivanochko, T.: High resolution dinoflagellate cyst record of environmental change in Effingham Inlet (British Columbia, Canada) over the last millennium, Palaeogeogr. Palaeocl., 441, 787-810, https://doi.org/10.1016/j.palaeo.2015.10.026, 2016.

Calbet, A.: The trophic roles of microzooplankton in marine systems, ICES J. Mar. Sci., 65, 325-331, https://doi.org/10.1093/icesjms/fsn013, 2008.

Calvert, S. E., Piper, D. Z., Thunell, R. C., and Astor, Y.: Elemental settling and burial fluxes in the Cariaco Basin, Mar. Chem., 177, 607-629, https://doi.org/10.1016/j.marchem.2015.10.001, 2015.

Dale, A. L. and Dale, B.: Dinoflagellate contributions to the sediment flux of the Nordic seas, in: Dinoflagellate Contributions to the Deep Sea, edited by: Honjo, S., Woods Hole Oceanographic Institution, 45-75, 1992.

Dale, B.: Dinoflagellate contributions to the open ocean sediment flux, in: Dinoflagellate Contributions to the Deep Sea, edited by: Honjo, S., Woods Hole Oceanographic Institution, 1-32, 1992.

Dale, B.: Dinoflagellate cyst ecology: Modeling and geological applications, in: Palynology: Principles and Applications, edited by: Jansonius, J. and McGregor, D. C., AASP Foundation, Salt Lake City, UT, 1249-1275, 1996.

Dale, B.: Eutrophication signals in the sedimentary record of dinoflagellate cysts in coastal waters, J. Sea Res., 61, 103-113, https://doi.org/10.1016/j.seares.2008.06.007, 2009.

Dale, B., Montresor, M., Zingone, A., and Zonneveld, K.: The cystmotile stage relationships of the dinoflagellates Diplopelta symmetrica and Diplopsalopsis latipeltata, Eur. J. Phycol., 28, 129137, https://doi.org/10.1080/09670269300650211, 1993.

Dale, B., Dale, A. L., and Jansen, J. H. F.: Dinoflagellate cysts as environmental indicators in surface sediments from the Congo deep-sea fan and adjacent regions, Palaeogeogr. Palaeocl., 185, 309-338, https://doi.org/10.1016/s0031-0182(02)00380-2, 2002.

Deuser, W. G.: Cariaco Trench - Oxidation of organic matter and residence time of anoxic water, Nature, 242, 601-603, https://doi.org/10.1038/242601b0, 1973. 
de Vernal, A., Henry, M., Matthiessen, J., Mudie, P. J., Rochon, A., Boessenkool, K. P., Eynaud, F., Grøsfjeld, K., Guiot, J., Hamel, D., Harland, R., Head, M. J., Kunz-Pirrung, M., Levac, E., Loucheur, V., Peyron, O., Pospelova, V., Radi, T., Turon, J. L., and Voronina, E.: Dinoflagellate cyst assemblages as tracers of sea-surface conditions in the northern North Atlantic, Arctic and sub-Arctic seas: The new " $n=677$ " data base and its application for quantitative palaeoceanographic reconstruction, J. Quaternary Sci., 16, 681-698, 2001.

Ellegaard, M. and Moestrup, O.: Fine structure of the flagellar apparatus and morphological details of Gymnodinium nolleri sp. nov. (Dinophyceae), an unarmored dinoflagellate producing a microreticulate cyst, Phycologia, 38, 289-300, https://doi.org/10.2216/i0031-8884-38-4-289.1, 1999.

Ellegaard, M., Dale, B., Mertens, K. N., Pospelova, V., and Ribeiro, S.: Dinoflagellate cysts as proxies for Holocene and recent environmental change in estuaries: Diversity, abundance and morphology, in: Applications of Paleoenvironmental Techniques in Estuarine Studies, Developments in Paleoenvironmental Research 20, edited by: Weckström, K., Saunders, K., Gell, P., and Skilbeck, G., Springer, Berlin, Germany, 295-312, 2017.

Elmore, A. C., Thunell, R. C., Styles, R., Black, D., Murray, R. W., Martinez, N., and Astor, Y.: Quantifying the seasonal variations in fluvial and eolian sources of terrigenous material to Cariaco Basin, Venezuela, J. S. Am. Earth Sci., 27, 197-210, https://doi.org/10.1016/j.jsames.2008.11.002, 2009.

Enfield, D. B. and Mayer, D. A.: Tropical Atlantic sea surface temperature variability and its relation to El NiñoSouthern Oscillation, J. Geophys. Res.-Oceans, 102, 929-945, https://doi.org/10.1029/96jc03296, 1997.

Foreman, M. G. G., Lee, D. K., Morrison, J., Macdonald, S., Barnes, D., and Williams, I. V.: Simulations and retrospective analyses of Fraser watershed flows and temperatures, Atmosphere-Ocean, 39, 89-105, 2001.

Fujii, R. and Matsuoka, K.: Seasonal change of dinoflagellates cyst flux collected in a sediment trap in Omura Bay, West Japan, J. Plankton Res., 28, 131-147, https://doi.org/10.1093/plankt/fbi106, 2006.

Giannini, A., Cane, M. A., and Kushnir, Y.: Interdecadal changes in the ENSO teleconnection to the Caribbean region and the North Atlantic Oscillation, J. Climate, $14, \quad 2867-2879$, https://doi.org/10.1175/15200442(2001)014<2867:icitet>2.0.co;2, 2001.

Goñi, M. A., Aceves, H. L., Thunell, R. C., Tappa, E., Black, D., Astor, Y., Varela, R., and Müller-Karger, F.: Biogenic fluxes in the Cariaco Basin: A combined study of sinking particulates and underlying sediments, Deep-Sea Res. Pt. I, 50, 781-807, https://doi.org/10.1016/s0967-0637(03)00060-8, 2003.

Goñi, M. A., Aceves, H., Benitez-Nelson, B., Tappa, E., Thunell, R., Black, D. E., Müller-Karger, F., Astor, Y., and Varela, R.: Oceanographic and climatologic controls on the compositions and fluxes of biogenic materials in the water column and sediments of the Cariaco Basin over the late Holocene, Deep-Sea Res. Pt. I, 56, 614-640, https://doi.org/10.1016/j.dsr.2008.11.010, 2009.

González, C., Dupont, L. M., Mertens, K., and Wefer, G.: Reconstructing marine productivity of the Cariaco Basin during Marine Isotope Stages 3 and 4 using organic- walled dinoflagellate cysts, Paleoceanography, 23, PA3215, https://doi.org/10.1029/2008pa001602, 2008.

Gordon, A. L.: Circulation in the Caribbean Sea, J. Geophys. Res., 72, 6207-6223, https://doi.org/10.1029/JZ072i024p06207, 1967.

Harland, R. and Pudsey, C. J.: Dinoflagellate cysts from sediment traps deployed in the Bellingshausen, Weddell and Scotia seas, Antarctica, Mar. Micropaleontol., 37, 77-99, https://doi.org/10.1016/s0377-8398(99)00016-x, 1999.

Harland, R., Nordberg, K., and Robijn, A.: Latest Holocene dinoflagellate cyst records from the west coast of Sweden and their impact on the interpretation of environmental change, Biological and Geological Perspectives of Dinoflagellates, edited by: Lewis, J. M., Marret, F., and Bradley, L. R., 43-54, 2013.

Head, M. J.: Modern dinoflagellate cysts and their biological affinities, in: Palynology: Principles and Applications, edited by: Jansonius, J. and McGregor, D. C., AASP Foundation, Salt Lake City, UT, 1197-1248, 1996.

Head, M. J.: Echinidinium zonneveldiae sp. nov., a dinoflagellate cyst from the late Pleistocene of the Baltic sea, northern Europe, J. Micropalaeontol., 21, 169-173, 2002.

Heikkilä, M., Pospelova, V., Hochheim, K. P., Kuzyk, Z. Z. A., Stern, G. A., Barber, D. G., and Macdonald, R. W.: Surface sediment dinoflagellate cysts from the Hudson Bay system and their relation to freshwater and nutrient cycling, Mar. Micropaleontol., 106, 79-109, https://doi.org/10.1016/j.marmicro.2013.12.002, 2014.

Heikkilä, M., Pospelova, V., Forest, A., Stern, G. A., Fortier, L., and Macdonald, R. W.: Dinoflagellate cyst production over an annual cycle in seasonally ice-covered Hudson Bay, Mar. Micropaleontol., 125, 1-24, https://doi.org/10.1016/j.marmicro.2016.02.005, 2016.

Ho, T. Y., Scranton, M. I., Taylor, G. T., Varela, R., Thunell, R. C., and Müller-Karger, F.: Acetate cycling in the water column of the Cariaco Basin: Seasonal and vertical variability and implication for carbon cycling, Limnol. Oceanogr., 47, 1119-1128, 2002.

Honjo, S. and Doherty, K. W.: Large aperture time-series sediment traps - Design objectives, construction and application, Deep-Sea Res. Pt. A, 35, 133-149, https://doi.org/10.1016/01980149(88)90062-3, 1988.

Howe, J. A., Harland, R., Cottier, F. R., Brand, T., Willis, K. J., Berge, J. R., Grøsfjeld, K., and Eriksson, A.: Dinoflagellate cysts as proxies for palaeoceanographic conditions in Arctic fjords, Fjord Systems and Archives, 344, 61-74, https://doi.org/10.1144/sp344.6, 2010.

Huffman, G. J., Bolvin, D. T., and Adler, R. F.: GPCP Version 1.2 One-Degree Daily Precipitation Data Set, in, Research Data Archive at the National Center for Atmospheric Research, Computational and Information Systems Laboratory, Boulder, CO, 2016.

Hughen, K. A., Overpeck, J. T., Peterson, L. C., and Trumbore, S.: Rapid climate changes in the tropical Atlantic region during the last deglaciation, Nature, 380, 51-54, https://doi.org/10.1038/380051a0, 1996.

Hughen, K. A., Southon, J. R., Lehman, S. J., and Overpeck, J. T.: Synchronous radiocarbon and climate shifts during the last deglaciation, Science, 290, 1951-1954, https://doi.org/10.1126/science.290.5498.1951, 2000. 
Jacobson, D. M. and Anderson, D. M.: Widespread phagocytosis of ciliates and other protists by marine mixotrophic and heterotrophic thecate dinoflagellates, J. Phycol., 32, 279-285, https://doi.org/10.1111/j.0022-3646.1996.00279.x, 1996.

Jeong, H. J.: The ecological roles of heterotrophic dinoflagellates in marine planktonic community, J. Eukaryot. Microbiol., 46, 390396, https://doi.org/10.1111/j.1550-7408.1999.tb04618.x, 1999.

Jeong, H. J., Yoo, Y. D., Kim, J. S., Seong, K. A., Kang, N. S., and Kim, T. H.: Growth, feeding and ecological roles of the mixotrophic and heterotrophic dinoflagellates in marine planktonic food webs, Ocean Sci. J., 45, 65-91, 2010.

Kawami, H. and Matsuoka, K.: A new cyst-theca relationship for Protoperidinium parthenopes Zingone \& Montresor 1988 (Peridiniales, Dinophyceae), Palynology, 33, 11-18, 2009.

Krepakevich, A. and Pospelova, V.: Tracing the influence of sewage discharge on coastal bays of southern Vancouver Island (BC, Canada) using sedimentary records of phytoplankton, Cont. Shelf Res., 30, 1924-1940, https://doi.org/10.1016/j.csr.2010.09.002, 2010.

Kudela, R. M. and Gobler, C. J.: Harmful dinoflagellate blooms caused by Cochlodinium sp.: Global expansion and ecological strategies facilitating bloom formation, Harmful Algae, 14, 7186, https://doi.org/10.1016/j.hal.2011.10.015, 2012.

Lange, C. B., Weinheimer, A. L., Reid, F. M. H., Tappa, E., and Thunell, R. C.: Response of siliceous microplankton from the Santa Barbara Basin to the 1997-98 El Niño event, California Cooperative Oceanic Fisheries Investigations Reports, 41, 186193, 2000.

Lentin, J. K. and Williams, G. L.: Fossil dinoflagellates: Index to genera and species, AASP Contribution Series, Dallas, TX, 856 pp., 1993.

Lep̌̌, J. and Šmilauer, P.: Multivariate analysis of ecological data using Canoco ${ }^{\mathrm{TM}}$, Cambridge University Press, Cambridge, UK, p. 283, 2003.

Li, Z., Han, M.-S., Matsuoka, K., Kim, S.-Y., and Shin, H. H.: Identification of the resting cyst of Cochlodinium polykrikoides Margalef (Dinophyceae, Gymnodiniales) in Korean coastal sediments, J. Phycol., 51, 204-210, https://doi.org/10.1111/jpy.12252, 2015.

Limoges, A., Kielt, J. F., Radi, T., Ruiz-Fernandez, A. C., and de Vernal, A.: Dinoflagellate cyst distribution in surface sediments along the south-western Mexican coast $\left(14.76^{\circ} \mathrm{N}\right.$ to $\left.24.75^{\circ} \mathrm{N}\right)$, Marine Micropaleontology, 76, 104-123, https://doi.org/10.1016/j.marmicro.2010.06.003, 2010.

Liu, T. T., Mertens, K. N., Ribeiro, S., Ellegaard, M., Matsuoka, K., and $\mathrm{Gu}, \mathrm{H}$. F.: Cyst-theca relationships and phylogenetic positions of Peridiniales (Dinophyceae) with two anterior intercalary plates, with description of Archaeperidinium bailongense sp. nov. and Protoperidinium fuzhouense sp. nov., Phycol. Res., 63, 134-151, https://doi.org/10.1111/pre.12081, 2015.

Lorenzoni, L., Hu, C. M., Varela, R., Arias, G., Guzman, L., and Müller-Karger, F.: Bio-optical characteristics of Cariaco Basin (Caribbean Sea) waters, Cont. Shelf Res., 31, 582-593, https://doi.org/10.1016/j.csr.2010.12.013, 2011.

Maher, L. J.: Statistics for microfossil concentration measurements employing samples spiked with marker grains, Rev. Palaeobot. Palyno., 32, 153-191, https://doi.org/10.1016/00346667(81)90002-6, 1981.
Margalef, R.: Hidrografía y fitoplancton de un área marina de la costa meridional de Puerto Rico, Investigación Perquera, 18, $33-$ 96, 1961.

Marshall, B. J., Thunell, R. C., Henehan, M. J., Astor, Y., and Wejnert, K. E.: Planktonic foraminiferal area density as a proxy for carbonate ion concentration: A calibration study using the Cariaco Basin ocean time series, Paleoceanography, 28, 363-376, https://doi.org/10.1002/palo.20034, 2013.

Matsuoka, K.: Eutrophication process recorded in dinoflagellate cyst assemblages - A case of Yokohama port, Tokyo Bay, Japan, Sci. Total Environ., 231, 17-35, https://doi.org/10.1016/s00489697(99)00087-x, 1999.

Matsuoka, K. and Iwataki, M.: Present status in study on a harmful unarmored dinoflagellate Cochlodinium polykrikoides Margalef, Bulletin of the Plankton Society of Japan, 51, 38-45, 2004.

Matsuoka, K., Kobayashi, S., and Gains, G.: A new species of the genus Ensiculifera (Dinophyceae); its cyst and motile forms, Bulletin of Plankton Society of Japan, 37, 127-144, 1990.

Matsuoka, K., Kawami, H., Fujii, R., and Iwataki, M.: Further examination of the cyst-theca relationship of Protoperidinium thulesense (Peridiniales, Dinophyceae) and the phylogenetic significance of round brown cysts, Phycologia, 45, 632-641, https://doi.org/10.2216/05-42.1, 2006.

Matsuoka, K., Kawami, H., Nagai, S., Iwataki, M., and Takayama, H.: Re-examination of cyst-motile relationships of Polykrikos kofoidii Chatton and Polykrikos schwartzii Butschli (Gymnodiniales, Dinophyceae), Rev. Palaeobot. Palyno., 154, 79-90, https://doi.org/10.1016/j.revpalbo.2008.12.013, 2009.

Mertens, K. N., González, C., Delusina, I., and Louwye, S.: 30000 years of productivity and salinity variations in the Late Quaternary Cariaco Basin revealed by dinoflagellate cysts, Boreas, 38, 647-662, https://doi.org/10.1111/j.1502-3885.2009.00095.x, 2009a.

Mertens, K. N., Verhoeven, K., Verleye, T., Louwye, S., Amorim, A., Ribeiro, S., Deaf, A. S., Harding, I. C., De Schepper, S., Gonzalez, C., Kodrans-Nsiah, M., De Vernal, A., Henry, M., Radi, T., Dybkjaer, K., Poulsen, N. E., Feist-Burkhardt, S., Chitolie, J., Heilmann-Clausen, C., Londeix, L., Turon, J. L., Marret, F., Matthiessen, J., McCarthy, F. M. G., Prasad, V., Pospelova, V., Hughes, J. E. K., Riding, J. B., Rochon, A., Sangiorgi, F., Welters, N., Sinclair, N., Thun, C., Soliman, A., Van Nieuwenhove, N., Vink, A., and Young, M.: Determining the absolute abundance of dinoflagellate cysts in recent marine sediments: The Lycopodium marker-grain method put to the test, Rev. Palaeobot. Palyno., 157, 238-252, https://doi.org/10.1016/j.revpalbo.2009.05.004, 2009b.

Mertens, K. N., Price, A. M., and Pospelova, V.: Determining the absolute abundance of dinoflagellate cysts in recent marine sediments II: Further tests of the Lycopodium marker-grain method, Rev. Palaeobot. Palyno., 184, 74-81, https://doi.org/10.1016/j.revpalbo.2012.06.012, 2012.

Mertens, K. N., Yamaguchi, A., Takano, Y., Pospelova, V., Head, M. J., Radi, T., Piénkowski, A. J., de Vernal, A., Kawami, H., and Matsuoka, K.: A new heterotrophic dinoflagellate from the Northeastern Pacific, Protoperidinium fukuyoi: Cyst-theca relationship, phylogeny, distribution and ecology, J. Eukaryot. Microbiol., 60, 545-563, https://doi.org/10.1111/jeu.12058, 2013.

Montes, E., Thunell, R., Müller-Karger, F. E., Lorenzoni, L., Tappa, E., Troccoli, L., Astor, Y., and Varela, R.: Sources of 
$\delta^{15} \mathrm{~N}$ variability in sinking particulate nitrogen in the Cariaco Basin, Venezuela, Deep-Sea Res. Pt. II, 93, 96-107, https://doi.org/10.1016/j.dsr2.2013.01.006, 2013.

Morquecho, L. and Lechuga-Devéze, C. H.: Seasonal occurrence of planktonic dinoflagellates and cyst production in relationship to environmental variables in subtropical Bahia Concepción, Gulf of California, Bot. Mar., 47, 313-322, https://doi.org/10.1515/bot.2004.037, 2004.

Morrison, J. M. and Smith, O. P.: Geostrophic transport variability along the Aves Ridge in the eastern Caribbean Sea during 1985-1986, J. Geophys. Res.-Oceans, 95, 699-710, https://doi.org/10.1029/JC095iC01p00699, 1990.

Mortlock, R. A. and Froelich, P. N.: A simple method for the rapid determination of biogenic opal in pelagic marine sediments, Deep-Sea Res. Pt. A, 36, 1415-1426, https://doi.org/10.1016/0198-0149(89)90092-7, 1989.

Müller-Karger, F. and Castro, R. A.: Mesoscale processes affecting phytoplankton abundance in the southern Caribbean Sea, Cont. Shelf Res., 14, 199-221, 1994.

Müller-Karger, F. E., McClain, C. R., Fisher, T. R., Esaias, W. E., and Varela, R.: Pigment distribution in the Caribbean Sea: Observations from space, Prog. Oceanogr., 23, 23-64, https://doi.org/10.1016/0079-6611(89)90024-4, 1989.

Müller-Karger, F., Varela, R., Thunell, R., Scranton, M., Bohrer, R., Taylor, G., Capelo, J., Astor, Y., Tappa, E., Ho, T. Y., and Walsh, J. J.: Annual cycle of primary production in the Cariaco Basin: Response to upwelling and implications for vertical export, J. Geophys. Res.-Oceans, 106, 4527-4542, https://doi.org/10.1029/1999jc000291, 2001.

Müller-Karger, F., Varela, R., Thunell, R., Astor, Y., Zhang, H. Y., Luerssen, R., and $\mathrm{Hu}, \mathrm{C}$. M.: Processes of coastal upwelling and carbon flux in the Cariaco Basin, Deep-Sea Res. Pt. II, 51, 927943, https://doi.org/10.1016/j.dsr2.2003.10.010, 2004.

Naustvoll, L. J.: Prey size spectra and food preferences in thecate heterotrophic dinoflagellates, Phycologia, 39, 187-198, https://doi.org/10.2216/i0031-8884-39-3-187.1, 2000.

Nelson, D. M., Tréguer, P., Brzezinski, M. A., Leynaert, A., and Quéguiner, B.: Production and dissolution of biogenic silica in the ocean - Revised global estimates, comparison with regional data and relationship to biogenic sedimentation, Global Biogeochem. Cy., 9, 359-372, https://doi.org/10.1029/95gb01070, 1995.

Osterman, D., Karbott, D., and Curry, W.: Automated system to measure the carbonate concentration of sediments, Woods Hole Oceanogr. Inst., Woods Hole, Mass., 1990.

Peterson, L. C., Overpeck, J. T., Kipp, N. G., and Imbrie, J.: A high-resolution Late Quaternary upwelling record from the anoxic Cariaco Basin, Venezuela, Paleoceanography, 6, 99-119, https://doi.org/10.1029/90pa02497, 1991.

Peterson, L. C., Haug, G. H., Hughen, K. A., and Rohl, U.: Rapid changes in the hydrologic cycle of the tropical Atlantic during the last glacial, Science, 290, 1947-1951, https://doi.org/10.1126/science.290.5498.1947, 2000.

Pinckney, J. L., Benitez-Nelson, C. R., Thunell, R. C., MüllerKarger, F., Lorenzoni, L., Troccoli, L., and Varela, R.: Phytoplankton community structure and depth distribution changes in the Cariaco Basin between 1996 and 2010, Deep-Sea Res. Pt. I, 101, 27-37, https://doi.org/10.1016/j.dsr.2015.03.004, 2015.
Pitcher, G. C. and Joyce, L. B.: Dinoflagellate cyst production on the southern Namaqua shelf of the Benguela upwelling system, J. Plankton Res., 31, 865-875, https://doi.org/10.1093/plankt/fbp040, 2009.

Pospelova, V. and Kim, S. J.: Dinoflagellate cysts in recent estuarine sediments from aquaculture sites of southern South Korea, Mar. Micropaleontol., 76, 37-51, https://doi.org/10.1016/j.marmicro.2010.04.003, 2010.

Pospelova, V., Chmura, G. L., Boothman, W. S., and Latimer, J. S.: Spatial distribution of modern dinoflagellate cysts in polluted estuarine sediments from Buzzards Bay (Massachusetts, USA) embayments, Mar. Ecol.-Prog. Ser., 292, 23 40, https://doi.org/10.3354/meps292023, 2005.

Pospelova, V., de Vernal, A., and Pedersen, T. F.: Distribution of dinoflagellate cysts in surface sediments from the northeastern Pacific Ocean $\left(43-25^{\circ} \mathrm{N}\right)$ in relation to sea-surface temperature, salinity, productivity and coastal upwelling, Mar. Micropaleontol., 68, 21-48, https://doi.org/10.1016/j.marmicro.2008.01.008, 2008.

Pospelova, V., Esenkulova, S., Johannessen, S. C., O’Brien, M. C., and Macdonald, R. W.: Organic-walled dinoflagellate cyst production, composition and flux from 1996 to 1998 in the central Strait of Georgia (BC, Canada): A sediment trap study, Mar. Micropaleontol., 75, 17-37, https://doi.org/10.1016/j.marmicro.2010.02.003, 2010.

Pospelova, V., Price, A. M., and Pedersen, T. F.: Palynological evidence for late quaternary climate and marine primary productivity changes along the California margin, Paleoceanography, 30, 877-894, https://doi.org/10.1002/2014pa002728, 2015.

Pospelova, V., Zonneveld, K. A. F., Heikkilä, M., Bringué, M., Price A. M., and Matsuoka, K.: Seasonality in Spiniferites cyst production: A review of sediment trap studies, Palynology, https://doi.org/10.1080/01916122.2018.1465738, online first, 2018.

Prebble, J. G., Crouch, E. M., Carter, L., Cortese, G., and Nodder, S. D.: Dinoflagellate cysts from two sediment traps east of New Zealand, Mar. Micropaleontol., 104, 25-37, https://doi.org/10.1016/j.marmicro.2013.08.003, 2013.

Price, A. M. and Pospelova, V.: High-resolution sediment trap study of organic-walled dinoflagellate cyst production and biogenic silica flux in Saanich Inlet (BC, Canada), Mar. Micropaleontol., 80, 18-43, https://doi.org/10.1016/j.marmicro.2011.03.003, 2011.

Price, A. M., Gurdebeke, P. R., Mertens, K. N., and Pospelova, V.: Determining the absolute abundance of dinoflagellate cysts in recent marine sediments III: Identifying the source of Lycopodium loss during palynological processing and further testing of the Lycopodium marker-grain method, Rev. Palaeobot. Palyno., 226, 78-90, https://doi.org/10.1016/j.revpalbo.2015.12.009, 2016.

Radi, T. and de Vernal, A.: Dinocysts as proxy of primary productivity in mid-high latitudes of the northern hemisphere, Mar. Micropaleontol., 68, 84-114, https://doi.org/10.1016/j.marmicro.2008.01.012, 2008.

Ragueneau, O., Treguer, P., Leynaert, A., Anderson, R. F., Brzezinski, M. A., DeMaster, D. J., Dugdale, R. C., Dymond, J., Fischer, G., Francois, R., Heinze, C., Maier-Reimer, E., Martin-Jezequel, V., Nelson, D. M., and Queguiner, B.: A review of the Si cycle in the modem ocean: Recent progress and missing gaps in the application of biogenic opal as a paleoproductivity proxy, Global 
Planet. Change, 26, 317-365, https://doi.org/10.1016/s09218181(00)00052-7, 2000.

Reid, P. C.: Peridiniacean and Glenodiniacean dinoflagellate cysts from the British isles, Nova Hedwigia, 29, 429-463, 1977.

Ribeiro, S. and Amorim, A.: Environmental drivers of temporal succession in recent dinoflagellate cyst assemblages from a coastal site in the North-East Atlantic (Lisbon Bay, Portugal), Mar. Micropaleontol., 68, 156-178, https://doi.org/10.1016/j.marmicro.2008.01.013, 2008.

Richards, F. A.: The Cariaco Basin (Trench), Oceanogr. Mar. Biol., 13, 11-67, 1975.

Richards, F. A. and Vaccaro, R. F.: The Cariaco Trench, an anaerobic basin in the Caribbean Sea, Deep-Sea Res., 3, 214-228, https://doi.org/10.1016/0146-6313(56)90005-3, 1956.

Rochon, A., de Vernal, A., Turon, J. L., Matthiessen, J., and Head, M. J.: Distribution of recent dinoflagellate cysts in surface sediments from the North Atlantic Ocean and adjacent seas in relation to sea-surface parameters. Contribution series no. 35, American Association of Stratigraphic Palynologists Foundation, Dallas, TX, 152 pp., 1999.

Romero, O. E., Thunell, R. C., Astor, Y., and Varela, R.: Seasonal and interannual dynamics in diatom production in the Cariaco Basin, Venezuela, Deep-Sea Res. Pt. I, 56, 571-581, https://doi.org/10.1016/j.dsr.2008.12.005, 2009.

Royer, T. C.: Hydrographic responses at a coastal site in the northern Gulf of Alaska to seasonal and interannual forcing, Deep-Sea Res. Pt. II, 52, 267-288, https://doi.org/10.1016/j.dsr2.2004.09.022, 2005.

Rueda-Roa, D. T.: On the spatial and temporal variability of upwelling in the southern Caribbean Sea and its influence on the ecology of phytoplankton and of the Spanish sardine (Sardinella aurita), $\mathrm{PhD}$, Marine Science, University of South Florida, p. 167, 2012.

Rueda-Roa, D. T. and Müller-Karger, F. E.: The southern Caribbean upwelling system: Sea surface temperature, wind forcing and chlorophyll concentration patterns, Deep-Sea Res. Pt. I, 78, 102114, https://doi.org/10.1016/j.dsr.2013.04.008, 2013.

Sherr, E. B. and Sherr, B. F.: Heterotrophic dinoflagellates: A significant component of microzooplankton biomass and major grazers of diatoms in the sea, Mar. Ecol.-Prog. Ser., 352, 187-197, https://doi.org/10.3354/meps07161, 2007.

Shin, H. H., Park, J. S., Kim, Y. O., Baek, S. H., Lim, D., and Yoon, Y. H.: Dinoflagellate cyst production and flux in Gamak Bay, Korea: A sediment trap study, Mar.Micropaleontol., 94-95, 72-79, https://doi.org/10.1016/j.marmicro.2012.06.005, 2012.

Shipe, R. F., Passow, U., Brzezinski, M. A., Graham, W. M., Pak, D. K., Siegel, D. A., and Alldredge, A. L.: Effects of the 1997-98 El Niño on seasonal variations in suspended and sinking particles in the Santa Barbara Basin, Prog. Oceanogr., 54, 105-127, https://doi.org/10.1016/s0079-6611(02)00045-9, 2002.

Smayda, T. J. and Trainer, V. L.: Dinoflagellate blooms in upwelling systems: Seeding, variability, and contrasts with diatom bloom behaviour, Prog. Oceanogr., 85, 92-107, https://doi.org/10.1016/j.pocean.2010.02.006, 2010.

Stockmarr, J.: Tablets with spores used in absolute pollen analysis, Pollen et Spores, 13, 616-621, 1971.

Susek, E., Zonneveld, K. A. F., Fischer, G., Versteegh, G. J. M., and Willems, H.: Organic-walled dinoflagellate cyst production in relation to upwelling intensity and lithogenic influx in the Cape
Blanc region (off north-west Africa), Phycol. Res., 53, 97-112, https://doi.org/10.1111/j.1440-1835.2005.tb00362.x, 2005.

Taylor, F. J. R.: The biology of dinoflagellates, Blackwell Scientific Publications, Oxford, 785 pp., 1987.

Taylor, G. T., Müller-Karger, F. E., Thunell, R. C., Scranton, M. I., Astor, Y., Varela, R., Ghinaglia, L. T., Lorenzoni, L., Fanning, K. A., Hameed, S., and Doherty, O.: Ecosystem responses in the southern Caribbean Sea to global climate change, P. Natl. Acad. Sci. USA, 109, 19315-19320, https://doi.org/10.1073/pnas.1207514109, 2012.

ter Braak, C. J. F. and Šmilauer, P.: CANOCO reference manual and CanoDraw for windows user's guide. Software for canonical community ordination (version 4.5). Microcomputer power, Ithaca, NY, 500 pp., 2002.

Thunell, R. C., Varela, R., Llano, M., Collister, J., Müller-Karger, F., and Bohrer, R.: Organic carbon fluxes, degradation, and accumulation in an anoxic basin: Sediment trap results from the Cariaco Basin, Limnol. Oceanogr., 45, 300-308, 2000.

Thunell, R., Benitez-Nelson, C., Varela, R., Astor, Y., and Müller-Karger, F.: Particulate organic carbon fluxes along upwelling-dominated continental margins: Rates and mechanisms, Global Biogeochem. Cy., 21, GB1022, https://doi.org/10.1029/2006gb002793, 2007.

Thunell, R., Benitez-Nelson, C., Müller-Karger, F., Lorenzoni, L., Fanning, K., Scranton, M., Varela, R., and Astor, Y.: $\mathrm{Si}$ cycle in the Cariaco Basin, Venezuela: Seasonal variability in silicate availability and the $\mathrm{Si}: \mathrm{C}: \mathrm{N}$ composition of sinking particles, Global Biogeochem. Cy., 22, GB4001, https://doi.org/10.1029/2007gb003096, 2008.

Verleye, T. J., Pospelova, V., Mertens, K. N., and Louwye, S.: The geographical distribution and (palaeo)ecology of Selenopemphix undulata sp. nov., a new late Quaternary dinoflagellate cyst from the pacific ocean, Mar. Micropaleontol., 78, 65-83, https://doi.org/10.1016/j.marmicro.2010.10.001, 2011.

Wall, D.: Fossil microplankton in deep-sea cores from the Caribbean Sea, Paleontology, 10, 95-123, 1967.

Wall, D. and Dale, B.: "Living fossils" in western Atlantic plankton, Nature, 211, 1025-1026, https://doi.org/10.1038/2111025a0, 1966.

Wall, D. and Dale, B.: Modern dinoflagellate cysts and evolution of the Peridiniales, Micropaleontology, 14, 265-304, https://doi.org/10.2307/1484690, 1968.

Wall, D. and Dale, B.: The "hystricosphaerid" resting spore of the dinoflagellate Pyrodinium bahamense, plate, 1906, J. Phycol., 5, 140-149, 1969.

Williams, G. L., Fensome, R. A., and MacRae, R. A.: The Lentin and Williams index of fossil dinoflagellates 2017 edition, American Association of Stratigraphic Palynologists Contributions Series, 48, 2017.

Zonneveld, K. A. F.: New species of organic walled dinoflagellate cysts from modern sediments of the Arabian Sea (Indian Ocean), Rev. Palaeobot. Palyno., 97, 319-337, https://doi.org/10.1016/S0034-6667(97)00002-X, 1997.

Zonneveld, K. A. F. and Brummer, G. J. A.: (Palaeo-)ecological significance, transport and preservation of organic-walled dinoflagellate cysts in the Somali Basin, NW Arabian Sea, DeepSea Res. Pt. II, 47, 2229-2256, https://doi.org/10.1016/s09670645(00)00023-0, 2000. 
Zonneveld, K. A. F. and Jurkschat, T.: Bitectatodinium spongium (Zonneveld, 1997) Zonneveld et Jurkschat, comb. nov. from modem sediments and sediment trap samples of the Arabian sea (northwestern Indian Ocean): Taxonomy and ecological affinity, Rev. Palaeobot. Palyno., 106, 153-169, https://doi.org/10.1016/s0034-6667(99)00007-x, 1999.

Zonneveld, K. A. F. and Pospelova, V.: A determination key for modern dinoflagellate cysts, Palynology, 39, 387-409, https://doi.org/10.1080/01916122.2014.990115, 2015.

Zonneveld, K. A. F., Susek, E., and Fischer, G.: Seasonal variability of the organic-walled dinoflagellate cyst production in the coastal upwelling region off Cape Blanc (Mauritania): A five-year survey, J. Phycol., 46, 202-215, https://doi.org/10.1111/j.15298817.2009.00799.x, 2010.
Zonneveld, K. A. F., Marret, F., Versteegh, G. J. M., Bogus, K., Bonnet, S., Bouimetarhan, I., Crouch, E., de Vernal, A., Elshanawany, R., Edwards, L., Esper, O., Forke, S., Grøsfjeld, K., Henry, M., Holzwarth, U., Kielt, J. F., Kim, S. Y., Ladouceur, S., Ledu, D., Chen, L., Limoges, A., Londeix, L., Lu, S. H., Mahmoud, M. S., Marino, G., Matsuoka, K., Matthiessen, J., Mildenhal, D. C., Mudie, P., Neil, H. L., Pospelova, V., Qi, Y. Z., Radi, T., Richerol, T., Rochon, A., Sangiorgi, F., Solignac, S., Turon, J. L., Verleye, T., Wang, Y., Wang, Z. H., and Young, M.: Atlas of modern dinoflagellate cyst distribution based on 2405 data points, Rev. Palaeobot. Palyno., 191, 1-197, https://doi.org/10.1016/j.revpalbo.2012.08.003, 2013. 